NBER WORKING PAPER SERIES

\title{
LIFECYCLE EFFECTS OF A RECESSION ON HEALTH BEHAVIORS: BOOM, BUST, AND RECOVERY IN ICELAND
}

\author{
Tinna Laufey Ásgeirsdóttir \\ Hope Corman \\ Kelly Noonan \\ Nancy Reichman \\ Working Paper 20950 \\ http://www.nber.org/papers/w20950
NATIONAL BUREAU OF ECONOMIC RESEARCH
1050 Massachusetts Avenue
Cambridge, MA 02138
February 2015

The authors are grateful to Victoria Halenda for excellent research assistance and to the Icelandic Research Fund (grant number 130611-051) and The Directorate of Health in Iceland (formerly the Public Health Institute of Iceland), which funded the data collection and permitted its usage for this project. We also thank Lysi Ltd. for the data on fish oil prices. The views expressed herein are those of the authors and do not necessarily reflect the views of the National Bureau of Economic Research.

NBER working papers are circulated for discussion and comment purposes. They have not been peerreviewed or been subject to the review by the NBER Board of Directors that accompanies official NBER publications.

(C) 2015 by Tinna Laufey Ásgeirsdóttir, Hope Corman, Kelly Noonan, and Nancy Reichman. All rights reserved. Short sections of text, not to exceed two paragraphs, may be quoted without explicit permission provided that full credit, including $(\mathrm{C}$ notice, is given to the source. 
Lifecycle Effects of a Recession on Health Behaviors: Boom, Bust, and Recovery in Iceland Tinna Laufey Ásgeirsdóttir, Hope Corman, Kelly Noonan, and Nancy Reichman NBER Working Paper No. 20950

February 2015

JEL No. D1,I1,J2

\begin{abstract}
This study uses individual-level longitudinal data from Iceland, a country that experienced a severe economic crisis in 2008 and substantial recovery by 2012, to investigate the extent to which the effects of a recession on health behaviors are lingering or short-lived and to explore trajectories in health behaviors from pre-crisis boom, to crisis, to recovery. Health-compromising behaviors (smoking, heavy drinking, sugared soft drinks, sweets, fast food, and tanning) declined during the crisis, and all but sweets continued to decline during the recovery. Health-promoting behaviors (consumption of fruit, fish oil, and vitamin/ minerals and getting recommended sleep) followed more idiosyncratic paths. Overall, most behaviors reverted back to their pre-crisis levels or trends during the recovery, and these short-term deviations in trajectories were probably too short-lived in this recession to have major impacts on health or mortality. A notable exception is for alcohol consumption, which declined dramatically during the crisis years, continued to fall (at a slower rate) during the recovery, and did not revert back to the pre-crisis upward trend during our observation period. These lingering effects, which directionally run counter to the pre-crisis upward trend, suggest that alcohol is a potential pathway by which recessions improve health and/or reduce mortality.
\end{abstract}

Tinna Laufey Ásgeirsdóttir

University of Iceland

Department of Economics

Oddi v. Sturlugotu

101 Reykjavik

Iceland

ta@hi.is

Hope Corman

Department of Economics

Rider University

2083 Lawrenceville Road

Lawrenceville, NJ 08648

and NBER

corman@ rider.edu

\author{
Kelly Noonan \\ Department of Economics \\ Rider University \\ 2083 Lawrence Road, Room SWG 306 \\ Lawrenceville, NJ 08648 \\ and NBER \\ knoonan@rider.edu \\ Nancy Reichman \\ Rutgers University \\ Robert Wood Johnson Medical School \\ Department of Pediatrics \\ Child Health Institute of New Jersey \\ 89 French St., Room 1348 \\ New Brunswick, NJ 08903 \\ reichmne@rutgers.edu
}




\section{Introduction}

Pioneering work by Ruhm (2000) found that although there is considerable evidence that longterm economic growth promotes population health, short-term downturns in economic activity counterintuitively lead to reduced mortality rates. That research spawned a wave of studies investigating the relationships between business cycles and health that has no doubt been fueled in recent years by the recent Great Recession in the U.S. and many other developed countries. A number of studies have examined effects on health behaviors, an important potential pathway.

As pointed out by Burgard, Alshire and Kalousova (2013), the Great Recession was noteworthy in terms of its severity, and the effects of such a deep downturn may differ from those of milder past recessions. Overall, the pre-Great Recession literature indicates that mortality and morbidity are lower during economic downturns, but that mental health appears to deteriorate during periods of higher unemployment (see Catalano et al., 2011 and Modrek et al., 2013), and there appears to be little consensus on the directional effects of business cycles on any health behavior, including smoking, binge drinking, and diets (see Ásgeirsdóttir et al., 2014). However, studies of the Great Recession in the U.S. and other developed countries have revealed no effects (Barrett \& O'Sullivan, 2013; Tekin, McClellan \& Minyard, 2013) or procyclical effects (Urbanos-Garrido \& López-Valcárcel, 2014) on self-assessed health, and studies have found mixed effects on mortality: Although van Gool and Pearson (2014) continued to find procyclical effects of poor economic conditions in countries on mortality in the context of the Great Recession, others found that this relationship no longer appeared to hold in the U.S. (Ruhm, 2013) or across countries (Toffolutti \& Suhrcke, 2014), and another study from the U.S. found a strong association between unemployment and mortality before the Great Recession, but a marginally positive relationship during the last decade of the 2000s, among individuals age 65 and over (Mclnerney \& Mellor, 2012). Finally, studies have continued to find a procyclical relationship between economic 
conditions and mental health in the context of the Great Recession (e.g., Ruhm, 2013; Toffolutti \& Suhrchke, 2014; Urbanos-Garrido \& Lopez-Valcarcel, 2014; van Gool \& Pearson, 2014).

Studies of the effects of the Great Recession on health behaviors represent a loose patchwork. In the U.S., Compton et al. (2014) found positive associations between individuals' employment status and substance use (alcohol, tobacco, and illicit drugs) during the Great Recession; Antillón, Lauderdale and Mullahy (2014) found that higher state unemployment rates during the Great Recession were associated with better sleep (less sleeplessness); and Smith, Ng and Popkin (2014) found that state unemployment rates (before and during the Great Recession) had no association with individuals' time spent cooking or eating away from home. Examining 23 European countries, Toffolutti and Suhrcke (2014) found no effects of unemployment during the Great Recession on alcohol consumption, although, in countries with a low level of "social protection" a counter-cyclical relationship was apparent (e.g., high unemployment was related to lower alcohol consumption). In Ireland, Barrett and O'Sullivan (2013) found that smoking was lower during the Great Recession than in the pre-crisis years (20062007) among adults age 50+. All of these studies were based on repeat cross-sectional data; that is, they did not observe the same individuals over time.

As discussed by Burgard, Alshire and Kalousova (2013), it is useful to distinguish between the effects of aggregate economic swings with those of the impact of these swings on individuals. For example, individuals may experience job loss, asset loss, or income loss which may be due to overall economic conditions, but may also be due to individual factors. Additionally, individuals may be affected by the societal impacts of a recession such as changes in prices or availability of goods, pollution, congestion, or other factors. The most straightforward strategy for disentangling the two effects is the use of individual level longitudinal data that spans a time period during which a clearly defined recession occurred. 
A few studies have examined the unemployment/health relationship using individual-level longitudinal data, where changes in employment status are modeled to affect changes in health status. Böckerman and Ilmakunnas (2009), using pre-Great Recession Finnish data, found that although those who are not employed have worse self-assessed health, transitions into and out of employment are not associated with that outcome. Granados et al. (2014), using a U.S. panel from 1979 to 1997 (pre-Great Recession), found that high state unemployment rates are associated with lower mortality rates, confirming the findings of most previous studies.

Three recent studies used individual-level longitudinal data to study the effects of labor market conditions or own unemployment on health behaviors during long time periods that included the Great Recession. Colman and Dave (2014), used two longitudinal datasets from the U.S. (PSID 1999-2009 and NLSY 1998-2010) in fixed- and random-effects models of the effects of own job loss on body-weight related behaviors (including cigarette smoking); the authors found evidence that job loss increases smoking among women (but not men) but decreases the number of cigarettes per day among smokers, and that job loss decreases fast food consumption. Latif (2014), using Canadian panel data from 1994 to 2009, found that higher provincial unemployment rates were associated with more binge drinking, but had no impact on the probability of being a smoker, and Ahn (2013), using longitudinal data from Korea from 2001 to 2010, found that reduced work hours (identified through government policy on the length of the work week) resulted in lower levels of smoking and binge drinking, as well as increases in regular exercise. However, none of these studies explicitly investigated effects of the Great Recession, and in Korea there was no recession during the time period studied.

Ásgeirsdóttir et al. (2014) used individual-level longitudinal data to estimate effects of the 2008 economic crisis in Iceland on a large set of health-compromising and health-promoting behaviors. Observing the same individuals one year before and one year after the crisis, they found that the macroeconomic shock led to reductions in seven different health-compromising behaviors (including 
binge drinking and smoking), as well as a number of health-promoting behaviors such as consumption of fruit and vegetables. The authors also found that for binge drinking, smoking, daily consumption of sugared soft drinks, fruit and vegetable consumption, and getting recommended sleep, the broad context of the macroeconomic downturn (such as price changes) appeared to be more important than changes in individual-level factors, including work hours, mortgage debt, real income, real assets, and mental health. For sweets, indoor tanning, fast food consumption, and daily consumption of fish oil, the individual factors explained half (for fish oil) or more of the change in consumption between the precrisis and crisis periods.

As far as we know, no research to date has investigated the effects of economic recession on health or health behaviors beyond the immediate aftermath of the recession or after the decline has ended or reversed. In particular, it is not known whether the effects of a recession on individuals' health behaviors are short-lived or enduring. If the effects represent mere "blips" in people's health behavior trajectories, the long-term effects of recessions on health-at least through the health behavior channel-are unlikely to be consequential. On the other hand, if the effects on health behaviors persist even after economic recovery, the long-term effects of recessions on health through individuals' health behaviors could be more substantial.

In this study, we address this knowledge gap using longitudinal data from Iceland, a country that has experienced a partial recovery from a severe economic crisis, and examining a number of different health behaviors of adults at three points in time-during the boom period leading up to the crisis, during the depths of the crisis, and after the economy had to a significant extent recovered. In particular, we expand the Ásgeirsdóttir et al. (2014) study by studying essentially the same set of health behaviors but adding a third important time point occurring after partial but significant economic recovery in 2012. As such, we consider the life cycle of a recession on health behaviors-a necessary 
avenue of inquiry in order to understand the importance of health behaviors as channels of effects between recessions and health outcomes.

\section{The Icelandic context}

The effects of the Great Recession on health and health behaviors have occurred in different structural, cultural, geographic, and policy contexts. For example, van Gool and Pearson (2014) considered whether overall health expenditures grew at a slower pace during the Great Recession than before the Great Recession in countries such as the U.S., France, and Germany, and even fell in countries such as Ireland, Iceland and Spain; Toffolutti and Suhrcke (2014) considered the role of overall social protection expenditures; and Ásgeirsdóttir et al. (2014) explored the impacts of the economic crisis in Iceland on prices for health-compromising and health-promoting goods. In this section, we describe the circumstances surrounding the boom, bust, and recovery in Iceland, to put the setting of the current study in context.

In 2001, the Icelandic krona became a floating currency (Kallestrup, 2008). With Iceland taking big steps towards becoming a modernized economy, foreign capital started flowing into the country. The global financial crisis hit Iceland hard in 2008 and resulted in a collapse of the nation's banking system. As a result, capital flowed out of the country until the implementation of capital controls in late November 2008 (Grønn \& Fredholm, 2013). Before the crisis, the country had been experiencing a boom; in the four years preceding the crisis, GDP growth averaged over $6 \%$ annually (Figure 1). In the first year following the crisis, 2009, GDP declined by 6.5\%. Based on World Bank estimates, Iceland's post-crisis rate of economic decline was not only larger than that in the United States or Britain, it was also larger than the declines in especially hard-hit countries such as Spain and Ireland (World Bank, 2014a). The recovery in Iceland also took place quickly, with a post-crisis average annual GDP growth rate of over 2\%. Based on World Bank figures, GDP growth in Iceland in 2012 was above the 
corresponding rate in other hard-hit countries such as Spain and Ireland, but was also above the rates in less severely affected countries such as Germany and France.

Icelandic economists attribute the quick recovery to three main factors: Flexible exchange rates, a flexible labor market, and capital controls (see Ólafsdóttir \& Einarsdóttir, 2013 and Guðmundsson, 2013). Specific labor market factors that are credited with preventing mass layoffs were lower nominal wages, fewer work hours, and less overtime. Iceland's dramatic recovery was lauded in international news stories. For example, Spiegel Online International credited Iceland's recovery as being "the fastest recovery on record" (Mingels, 2014, p. 2), Forbes referred to the recovery in Iceland as "a success story" deemed "fascinating" (Greenstein 2013, p. 1 and 2), and Dow Jones reported that Iceland is "coming back strongly" (Duxbury, 2014, p. 1). Based on the GDP growth statistics, domestic analyses, and news reports, it is clear that in a short period of time Iceland's economy went from boom to bust to substantial recovery.

As in many countries during the Great Recession, Iceland's unemployment rate more than doubled during the crisis (Figure 2). The pre-crisis unemployment rate was extremely low (less than $2 \%$ in 2007), so the large percentage increase during the crisis resulted in a much lower unemployment rate than similar percentage increases in other hard-hit countries such as Ireland and Spain (World Bank 2014b), which saw employment rates well over $10 \%$. But while those other countries experienced deflation during the worst years of the recession, Iceland experienced substantial price increases, largely due to the devaluation of the Icelandic krona by about $36 \%$ in exchange markets. Consumer prices jumped over 12\% between 2007 and 2008 and then another 12\% between 2008 and 2009 (Figure 3). The rise in the price level is also reflected in real wages, which fell by over $10 \%$ between their peak in 2007 and trough in 2010 (Figure 4). These large price increases not only reduced purchasing power, but they also resulted in increased debt obligations for many Icelanders as many mortgages and other debts 
were in foreign currencies (Ásgeirsdóttir et al., 2014). By 2010, overall consumer price increases reverted back to pre-crisis trends, and real wages returned to their pre-boom level.

As discussed in the literature (see Ásgeirsdóttir et al., 2014), deep recessions can affect individuals' health and health behaviors through their own circumstances, such as unemployment, or through society-wide factors such as environmental changes or changes in prices. In Iceland, while certain individuals may have become unemployed as a result of the crisis, all residents confronted large price increases, and most experienced a drop in real wages. Overall, in a relatively short period of 5 years, Icelanders experienced economic boom, then bust, then substantial recovery, with potential society-wide effects in addition to effects through changes in certain people's circumstances. These features make the Icelandic situation ideal for an individual-level longitudinal analysis of the effects of macroeconomic changes on health behaviors, which can change quickly but may take a long time to be reflected in health outcomes.

\section{Data}

The data used for this study come from a health and lifestyle survey "Heilsa og líđan" (Health and Wellbeing) carried out by the Directorate of Health in Iceland (previously the Public Health Institute of Iceland) in 2007, 2009, and 2012. The survey contained questions about health, illnesses, use of drugs, smoking and drinking, diet, health care, height and weight, accidents, exercise, sleep, and quality of life and other lifestyle related issues, as well as demographics and work related factors such as work hours and income. A stratified random sample of 9,807 Icelanders, ranging in age from 18 to 79 years of age, was drawn. Questionnaires were mailed at the end of October or the beginning of November in each survey year and almost of the respondents returned them by the end of the given year. The net response rate in 2007 was $60.8 \%$. Participants from 2007 who agreed to be contacted again also received the 2009 questionnaire; 69.3\% of the 2007 respondents participated in 2009. In 2012, 3,246 of respondents from the original sample completed questionnaires. This represents $88.7 \%$ of those who 
had agreed to be contacted again for that last wave. A total of 3,238 individuals, or $33.0 \%$ of the original sample, participated in all three waves of the survey.

Due to the stratification in the sampling process, the sample is somewhat older than the adult population of Iceland overall and more likely to live outside the capital region. There were six age groups by two residential groups, forming a total of 12 strata and all results presented here use sample weights to make the sample nationally representative (Jónsson et al., 2011; Guðlaugsson, Magnússon \& Jónsson, 2014).

\section{Measures}

We consider 10 different health behaviors for which information was collected at all three survey waves (2007, 2009, and 2012). These include measures of substance use, dietary behaviors, indoor tanning, and sleep, and largely correspond to those considered by Ásgeirsdóttir et al. (2014) for 2009 compared to 2007, with certain exceptions as noted.

For substance use, we coded individuals as smokers if they answered the question "Do you smoke?" with a yes, and as heavy drinkers if they provided information indicating at least once per month in response to the question "How often during the past 12 months, if ever, have you consumed at least 5 alcoholic drinks in one day?"1 ${ }^{1}$ For dietary behaviors, we used responses to questions about how often individuals consumed various categories of food to construct measures of daily (versus less than daily) consumption of sugar-containing soft drinks and sweets ${ }^{2}$, weekly (versus less than weekly) consumption of fast food (either at a fast-food restaurant or by taking home prepared foods), and daily (vs. less than daily) consumption of fruit, fish liver oil or fish oil capsules, and vitamins or minerals. ${ }^{3}$

\footnotetext{
${ }^{1}$ Having five or more drinks on one day is slightly different than the U.S. Centers for Disease Control's definition of "binge drinking," which is drinking five or more drinks in one sitting. Source: http://www.cdc.gov/alcohol/factsheets/binge-drinking.htm (accessed on January 20, 2015).

${ }^{2}$ The question asks about "sweets or chocolate."

${ }^{3}$ We do not consider the consumption of vegetables, which was examined by Ásgeirsdóttir et al. (2014) for 2007 and 2009, because the relevant question wording changed in 2012, precluding the construction of comparable
} 
Finally, we used responses to questions about how often within the last 12 months respondents sunbathed with indoor tanning lamps or tanning beds while "scantily dressed in order to receive as much sun or radiation as possible" and how many hours a night they generally sleep to create measures of indoor tanning (ever, versus never, in the past 12 months) and optimal sleep (7-9 hours of sleep per night, versus more or less than that, based on the U.S. Centers for Disease Control and Prevention (2012) recommendation for optimal amount of sleep). Smoking, heavy drinking, sugared soft drinks, sweets, fast food, and tanning are categorized as health-compromising behaviors and, and fruit, fish liver oil, vitamins/minerals, and optimal sleep are categorized as health promoting behaviors. ${ }^{4}$

Our models include the following time-varying sociodemographic characteristics: marital status, cohabitation status, ${ }^{5}$ household composition (other adult(s) besides partner, any children), home ownership, and rural residence (an area of fewer than 1,000 inhabitants), and we explore the roles of work hours, real income, and mental health as pathways through which the crisis may have impacted health behaviors.

The measures of labor market activity are based on two questions. In the first, respondents were asked to describe their work arrangements. We coded individuals as not working if they answered, "I do not work." In the second, respondents were asked how many hours they generally spend each week doing paid work. They were given 13 response options, including 0 , less than 1 (coded as 1 ), ten categories ranging from 1-3 hours to 50-59 hours, and a top category of 60 hours or more. We used the mid-points of each of the 1-3 through 50-59 ranges and coded responses of 60 hours or more as 60 .

measures across the three surveys. In addition, we consider vitamins or minerals, whereas the Ásgeirsdóttir et al. study used a measure that also considered supplements.

${ }^{4}$ See Lustig, Schmidt \& Brindis (2012) for a discussion of consumption of sugar (not limited to soft drinks) as a health-compromising behavior. According to the U.S. Centers for Disease Control and Prevention (2013), indoor tanning has been linked with skin cancers (including melanoma, the deadliest type) and cancers of the eye. Fish oil has been studied as a protective factor for heart health and believed to be a health-promoting product since it was found that Greenland Inuit people have lower risk of heart disease despite having high-fat diets (Mayo Clinic, 2015). Consumption of fish oil has a rich tradition in Iceland, where one of the country's explicit food-based dietary guidelines is to consume fish oil or other vitamin D sources daily (see Jeppesen, Bjerregaard \& Young, 2011).

${ }^{5}$ We include indicators for being married and for cohabiting with a partner but not being married, both compared to neither married nor cohabiting. 
We measure income using the following question: "In what range do you estimate the total income of all household members (e.g. spouse, children and parents) in your household (including yourself) to have been generally... within the past month or within the past 12 months." The respondents were told that this amount should include "all pre-tax income, such as salaries, overtime, differentials, bonuses, interest and dividends, grants/benefits, and pensions." Icelandic benefits come in multiple forms including child benefits, housing benefits, and interest relief. The benefits generally depend on the individual's labor-market income. In the survey, the response choices for income were in ten categories measured in millions of krona, ranging from "less than .9 million krona" and going up to a top category of "more than 18 million krona." Mid-points of the indicated ranges were used, with a topcode for the highest category. Individuals living alone were not asked this question. For those individuals, we used the responses to a question on individual income and coded those responses similarly. The price level in Iceland rose by about $27 \%$ between 2007 and 2009 and by about $44 \%$ between 2007 and 2012. To investigate changes in real income, we standardized to 2007 krona. That is, 2007 real income was equal to 2007 nominal income but 2009 real income was 2009 nominal income divided by 1.27 and 2012 real income was 2012 nominal income divided by 1.44 .

We created a measure of "anxiety or poor mental health" based on responses to the following two questions: (1) "Has having any of the following conditions interfered with your daily life in the past 12 months?" One of the response choices was anxiety. (2) "What is your general assessment of your mental health? Do you feel that it is very good, good, fair or poor?" If the respondent reported that anxiety interfered with his/her daily life in the past 12 months or that he/she considered his/her mental health to be poor, we coded him/her as having anxiety or poor mental health. We found that all results were insensitive to all alternative measures of mental health that could be created from the data.

Finally, in certain analyses, we include measures of the respondent's sex, age, and education. Education attainment is measured at 2009 and categorized as the U.S. equivalents of high school 
education or less, some college education (but not a four year degree), and at least four years of college education. $^{6}$

\section{Methods}

We exploit the economic crisis of 2008 in Iceland and the subsequent swift and substantial reversal that followed to investigate the lifecycle effects of a deep recession on health behaviors. Using 2007, 2009 and 2012 data, we estimate individual fixed-effects models, which implicitly control for unobserved time-invariant individual-level characteristics and, more importantly for our study, account for cross-period correlation in standard errors. In these models, we estimate each of the 10 health behaviors, with the key variables of interest being an indicator for 2009 to capture the effects of the crisis compared to 2007 (pre-crisis) and an indicator for 2012 to capture the effects of the recovery compared to the pre-crisis level. We estimate those models without any covariates, with the set of timevarying covariates described earlier, and with both time-varying covariates and potential mediators (work hours, real household income, and mental health) to assess the extent to which those factors appear to explain the effects of the year indicators. For each outcome, we estimate models for our main analysis sample (those completing 2007, 2009, and 2012 interviews who have non-missing data on the outcome or any right of the time-varying covariates or potential mediators), as well as for the subgroup of working age adults (25-61 years). Due to varying rates of missing data on outcome variables, the sample sizes are slightly different for each outcome.

To assess the potential importance of sample selection as a result of missing right-hand data items, we also estimate unadjusted models for the sample of respondents who participated in all three interviews and had non-missing data on the outcome, but may or may not have had missing data on right-hand variables. We compare results from that "full sample" to those from the main analysis

\footnotetext{
${ }^{6}$ The question on educational attainment was improved between waves and asked differently in 2009 than in 2007. Thus, we chose to treat education as time-invariant based first and foremost on the 2009 answers. Given the wide age range of individuals we are examining over a time period of five years, treating educational attainment as time-invariant seems reasonable, particularly for sub-analyses of working-age adults.
} 
sample (defined above), which is generally about one-third the size of the corresponding full sample.

Most studies of the effects of economic downturns have used such before-and-after designs, but with repeat cross-sectional, rather than longitudinal, data. As such, controlling for potential compositional changes in the population represents a key methodological challenge. Our study uses individual-level longitudinal data, allowing us to control for person-specific effects as well as relevant time-varying factors. Thus, compositional selection does not complicate our study. However, our study is potentially subject to other methodological challenges or potential sources of confounding: preexisting trends in health behaviors, potentially confounding changes in factors unrelated to the crisis, aging of the sample, and sample attrition.

Pre-existing trends

Relevant trend data are available for four of the outcomes of interest. Trends in the percentage of the population 18 and over that smokes daily, pure alcohol sales per capita for individuals age 15 and above, consumption of sweets (i.e., candy, chocolate) per capita, and fruit consumption per capita, are presented in Figures 5-8, respectively. From these figures, it is clear that the consumption of alcohol, fruit, and sweets were increasing before the crisis but subsequently declined. Alcohol and fruit consumption declined during the crisis (late 2008 through 2009), while the consumption of sweets appears to have experience a delayed reaction, with the decline taking place after 2009. Smoking had been declining prior to the crisis, but appeared to decline more rapidly during the crisis than during the years leading up to it. These sharp reductions did not persist into the early recovery period (2010-2012). For smoking, there was a very slight decline during the early recovery, which was less than the decline during the crisis; for alcohol, there was a leveling off; and for fruit and sweets, the decline in consumption completely reversed. These aggregate statistics do not provide a picture of the effects of the crisis and recovery on individual behaviors, as the trends may be confounded by demographic changes. However, they provide valuable context for interpreting the findings vis-à-vis these 4 health 
behaviors. For the other 6 behaviors, we are not able to contextualize our analyses in this way.

\section{Potentially confounding changes}

As discussed by Ásgeirsdóttir et al. (2014), Iceland enacted a smoking ban in restaurants and bars on June 1, 2007-five months prior to the first survey. However, those authors cited research indicating that although smoking bans may impact the quantity of consumption, they do not appear to impact smoking prevalence. Thus, the smoking ban in restaurants and bars in Iceland is not expected to have affected smoking prevalence in the country. In addition, it could not explain the recovery effects for smoking or the crisis or recovery effects for most other behaviors, which were not subject to legislative changes. The only other potentially relevant structural change of which we are aware was for indoor tanning; beginning in 2011, the government enacted a ban on indoor tanning for those under 18 years of age. ${ }^{7}$ Although this law does not directly apply to individuals in the age range we are studying, the number of tanning salons dropped by 12 , or $17 \%$, between 2009 and $2012 .{ }^{8}$ At about the same time, Denmark, which has strong connections to Iceland, launched a skin cancer prevention campaign and saw a large decline in indoor tanning use (Køster et al., 2011). These laws and policies, and publicity surrounding them, may have increased public awareness about the health risks of indoor tanning and led to general declines in indoor tanning in Iceland that were independent of the crisis. As such, it will be important to consider our estimates of the longer-term effects of the crisis on indoor tanning (i.e., the effects of the crisis during the recovery period, which is when the bulk of the policy change took place) in light of these potentially confounding changes.

Aging of the sample

Given our reliance on longitudinal rather than repeat cross-sectional data, observed crisis and recovery effects could theoretically be picking up aging effects. That is, every single individual in the sample aged two years between 2007 and 2009 and three years between 2009 and 2012, and health

\footnotetext{
${ }^{7}$ Source: http://www.althingi.is/altext/stit/2010.082.html. Accessed on January 20, 2015.

${ }^{8}$ Source: http://hagstofa.is/Hagtolur/Fyrirtaeki-og-velta/Fyrirtaeki). Accessed on January 20, 2015.
} 
behaviors can change with age, particularly at very young and old adult ages. Following Ásgeirsdóttir et al. (2014), we addressed this issue two ways: (1) estimating pooled probit models (which do not control for unobserved time invariant person-specific effects or adjust for cross-period correlation in standard errors) that control for age and other covariates, and (2) conducting analyses on the subsample of adults who were of working age (25-61 in 2007), ${ }^{9}$ a group for whom periods of $2-3$ years should normally have small effects on behaviors.

\section{Attrition}

Although the sampling weights that were applied adjust for attrition and non-response based on gender, age, and residence to produce nationally representative data, there may be some important, unaccounted for, differences between stayers (respondents who completed all three surveys) and leavers (those completed the initial survey in 2007 but did not complete the 2009 and 2012 surveys) that could bias our estimates. Weighted and unweighted differences between the two groups are presented in Appendix Table 1. In the weighted sample, stayers were older and were more likely to be married, to have a child in the household, to be homeowners, to be in good or very good health, to be working, and to be professionals. In the unweighted sample, there are few significant differences between leavers and stayers, but the pattern was almost identical to that for the weighted sample. Our analyses of the working age subsample should attenuate many of these differences.

\section{Results}

Health behaviors and other characteristics (weighted means) of our full analysis sample (those participating in all three survey waves and who had non-missing data on key analysis variables) and the subsample of working-age (25-61 years old in 2007) are presented in Table 1 for 2007, 2009, and 2012. Except for daily sweets, all health-compromising behaviors declined during the crisis (between 2007 and

9 Most young adults have completed their schooling by age 25 and the standard age to receive retirement pensions in Iceland is 67. Source: http://www.ssa.gov/policy/docs/progdesc/ssptw/2010-

2011/europe/iceland.html (accessed on January 20, 2014). Individuals who were under 62 in November of 2007 were under 67 in November of 2012. 
2009) and continued to decline for the full sample during the recovery (between 2009 and 2012). Fruit consumption declined between 2007 and 2009, but then increased beyond their pre-crisis levels during the recovery. Recommended sleep increased between 2007 and 2009, but declined during the recovery, while use of fish oil and vitamins/minerals remained constant or increased during the crisis and continued to increase during the recovery. Patterns for the working-age sample are similar to those for the full sample.

The proportions that were married increased over time. Not surprisingly, the mean number of hours worked declined during the crisis and then increased during the recovery, but as of 2012 had not reverted back to the pre-crisis (boom) level. The proportion of the working-age sample that was employed declined during the crisis and then increased although not quite up to the pre-crisis level. For the full sample, the proportion that was employed fell during the crisis, but did not recover during our observation period, suggesting that some older people may have decided to retire during the crisis. Real income dropped precipitously during the crisis and recovered somewhat afterward, but at 2012 was still well below the pre-crisis level. Finally, consistent with much research discussed earlier, anxiety or poor mental health increased during the crisis and then decreased during the recovery but did not revert to its boom level. Overall, these data confirm what we found in the aggregate statistics - that the economy in Iceland had recovered substantially but not completely by the end of 2012-as well as with findings of Ball (2014) that labor force participation does not fully revert back to pre-recession levels, even after economies recover.

In Tables 2 and 3, we present estimates from 4 linear fixed-effects regressions for each of the 10 health-related behaviors (health-compromising behaviors are in Table 2; health-promoting behaviors are in Table 3). For all models, coefficients are presented for 2009 (crisis) and 2012 (recovery) indicators, with 2007 (pre-crisis) as the reference year. We used 2007 (pre-crisis) as the reference year because we are interested in comparing short- (2009) and longer-term (2012) effects of the crisis. However, it is also 
possible to obtain estimates for the recovery period by subtracting the coefficient of the 2009 indicator from that of the 2007 indicator, and we show p-values for that particular comparison (i.e., from tests for significant differences between the 2009 and 2012 coefficients) for each model. All of the estimates are from fixed-effects models, which implicitly control for time-invariant individual-level characteristicseven those that cannot be observed.

For each behavior, the estimates in Panels 1 and 2 of Tables 2 and 3 are from models that include no covariates (that is, the only right-hand-side variables are indicators for 2009 and 2012) for the full and main analysis samples (defined earlier and in table notes), respectively. The coefficients from these unadjusted regressions capture the overall short- and longer-term effect of the crisis on individuals' behaviors, assuming that the behavioral changes were due entirely to changes in macroeconomic conditions. Estimates from Panel 1 are very similar to those from Panel 2, suggesting that data loss as a result of missing right-hand side variables is not consequential for our analyses.

For each behavior, Panel 3 in Tables 2 and 3 shows estimates from models that include timevarying covariates: married, cohabiting with a partner but not married, child(ren) in the household, living with an adult other than a partner, homeownership, and residing in a rural area. The coefficients of the year indicators in these regressions capture the short- and longer-term effects of the crisis on individuals' health behaviors. Panel 4 shows estimates from models that also include a set of potential mediating factors that capture the most obvious ways that economic conditions would be expected to affect individual's circumstances-hours worked, real income, and mental health. ${ }^{10}$ As such, the models in Panels 3 and 4 of Tables 2 and 3 net out the impacts of the crisis as it (potentially) affected individuals and the coefficients reflect the effects of economic conditions net of those individual-level effects. ${ }^{11}$

\footnotetext{
${ }^{10}$ In other models, not shown but available on request, we used an indicator for employed rather than hours worked. Results were similar.

${ }^{11}$ Questions about assets were not included in the 2012 survey, so we are unable to account for changes in real assets as Ásgeirsdóttir et al. (2014) did for 2009 vs. 2007.
} 
We guide the reader through the results for one behavior in detail (smoking, in Table 2). When no covariates are included in the fixed-effects regression based on our analysis sample (Panel 2), we find that individuals were 2.9 percentage points less likely to smoke in 2009 compared to 2007 (Row 2a) and 4.9 percentage points less likely to smoke in 2012 compared to 2007 (Row 2b). Both coefficients are significant at the $1 \%$ level, as is the difference between the two (Row $2 c$ ). When we add the time-varying covariates, the coefficients of the 2009 and 2012 indicators change little (Rows 3a \& b, compared to Rows $2 \mathrm{a} \& \mathrm{~b}$ ). Finally, adding the potential mediating factors (Rows $4 \mathrm{a} \& \mathrm{~b}$ ) results in substantial reductions of the coefficients of the 2009 and 2012 indicators (to 1.8 and 3.9 percentage points, respectively), suggesting that the effects on smoking operated to some extent through those channels.

For convenience to the reader, for each behavior, we indicate the percentage of the change in the effects of the crisis (between each pair of survey years) that resulted from including the individuallevel factors (both time-varying covariates and mediators) in the model (Panel 5). For 2009 vs. 2007 and 2012 vs. 2007, the percentage of change is computed by subtracting the coefficient for a given behavior in a given year in the model with no covariates (Panel 2; Row a or b) from the corresponding coefficient in Panel 4 (model which includes both time-varying covariates and mediators), dividing by the former, and multiplying by 100. For 2012 vs. 2009, we take the difference in coefficients between 2012 and 2009 in Panel 2, subtract the corresponding difference in coefficients in Panel 4, divide by the Panel 2 difference, and multiply by $100 .^{12}$

We find that individual-level changes in circumstances accounted for about $38 \%$ of the decrease in smoking between 2007 and 2009 (Row 5a), and about 20\% of the decrease in smoking between 2007 and 2012 (Row 5b). For the other health- compromising behaviors, individual-level changes explain less than one-quarter of the effects. For smoking, we find that the only statistically significant mediator is

\footnotetext{
${ }^{12}$ These values are only meaningful when coefficient in Panel 2 is statistically different from zero and when the absolute value of the coefficient is smaller in Panel 4 than in Panel 2.
} 
household income (see Appendix Table 2 for estimated effects of the crisis on the mediators and Appendix Tables $3 \& 4$ for estimated effects of each of the individual mediators on health behaviors).

Table 2 confirms the findings by Ásgeirsdóttir et al. (2014) - who did not restrict their sample to individuals who completed surveys in 2012 in addition to 2007 and 2009-that all of the healthcompromising behaviors declined between 2007 and 2009. In addition, we find that 5 of those 6 behaviors continued to decline between 2009 and 2012. For most specifications and outcomes, the coefficient of the 2012 indicator is greater in magnitude than that of the 2009 indicator.

For 3 of the health-compromising behaviors-smoking, binge drinking, and consumption of sweets-we are able to place our findings in context vis-à-vis pre-crisis trends due to the availability of national consumption time-series data (Figures 5, 6, and 7). For smoking, the percentage of the population that smoked daily declined by about .8 per year between 2000 and 2003 , by about 3.8 per year during the boom years of 2003 to 2007 , by 8.9 per year during the crisis period from 2007 to 2010, and by about 1.6 per year during the recovery years between 2010 and 2012 (Figure 5). Using our dichotomous measure of whether a person was a smoker, we found that the likelihood of smoking declined during the crisis years (in the range of 4.5 to $7.3 \%$ per year, depending on which model is considered) and then at a rate slightly above the pre-crisis rate (3.5 to $3.9 \%$ per year) during the recovery. ${ }^{13}$ The national data and our regression results, together, indicate that the crisis led to a brief accelerated decline in smoking but that smoking resumed its more moderate pre-crisis rate of decline as the recovery took hold.

For alcohol, the national statistics show that consumption of pure alcohol per capita (ages 15 and above) rose during the pre- and boom years by $3-4 \%$ per year, and then declined during the crisis and post-crisis years (by 3.1 and $1.5 \%$, per year respectively) (Figure 6). We found that the likelihood of

\footnotetext{
${ }^{13}$ For crisis years, for a given model we take the coefficient for 2009, divide by 2007 mean for the behavior, and divide by 2 to annualize to reflect the fact that it is a 2-year period. For post-crisis years, we take the coefficient for 2012, subtract it from coefficient for 2009, divide by the 2009 mean, and then divide by 3 to reflect that it is a 3 year period.
} 
binge drinking declined dramatically during the crisis years (5\% per year, regardless of the model considered) and then continued to fall at a slower rate (about 2-3\% per year) during the recovery but did not revert back to the pre-crisis upward trend.

The consumption of sweets displayed an even different trajectory, increasing by $2.2 \%$ per year before the boom, $.8 \%$ per year during the boom, and $1.2 \%$ per year during the crisis, but decreasing sharply during the recovery and then reverting back to its pre-crisis level (Figure 7). We found that the likelihood of consuming sweets daily decreased substantially during the crisis years (in the range of 11.7 to $13.9 \%$ per year, depending on which model is considered) and then rose by $6-7 \%$ per year during the recovery. Thus, for smoking and sweets, the crisis appeared to induce short term responses, but consumption quickly reverted back to the post-crisis trajectories with the recovery. For alcohol, the crisis appeared to induce a more permanent and dramatic shift in trajectory.

Because pre-2007 trend data for other health-compromising behaviors are not available, it is difficult to assess whether our estimated post-crisis declines in soft drinks, fast food, and tanning represent lingering effects of the crisis or reversions to pre-crisis trends. For fast food and soft drinks, we can (imperfectly) explore this issue by considering trends in the United States. According to data from a Gallup poll (Dugan, 2013), the consumption of fast food at least weekly decreased in the U.S. by about 7\% between 2003 and 2006, from 56 to 52\%. If the U.S. statistics are indicative of a global trend that included Iceland, our estimated decline of about 16\% in Iceland between 2007 and 2009 would represent a deviation in the long-term trend (i.e., a steeper decline), but the decline between 2009 and 2012 of about $2 \%$ would be consistent with the ongoing trend in fast food consumption. Thus, based on the available evidence, it appears the effects of the crisis on fast food consumption in Iceland were short lived. Similarly, sugared soft drink consumption declined in the U.S. between 2003 and 2007 (Kit et al., 2013). If Iceland's trend was similar to that in the U.S., then the steep decline in soft drink consumption in Iceland between 2007 and 2009 followed by an insignificant decline between 2009 and 2012 suggests 
that the effects of the crisis on soft drink consumption were short lived. For tanning, we cannot determine, or even speculate, whether the crisis effects were lingering or short lived because of the lack of trend data as well as the policy changes described earlier.

For health-promoting behaviors (Table 3), the crisis and recovery played out in behavior-specific ways. Daily consumption of fruit declined between 2007 and 2009 (Row 2a or 3a), but by 2012 had increased beyond its 2007 level (Row $2 b$ or $3 b$ ). Comparing the relevant figures from the same sets of rows: Daily fish oil consumption was higher in 2009 than in 2007 and higher still in 2012; daily vitamin/mineral consumption did not change between 2007 and 2009, but increased by almost 7 percentage points by 2012; and recommended sleep increased between 2007 and 2009, but reverted back to its pre-crisis level by 2012. In all specifications for each of the 4 health-promoting behaviors, the effects of 2012 were significantly different from those of 2009 (Row 2c or 3c), indicating that the crisis and recovery were characterized by distinct phases in individuals' health-promoting behavior trajectories. The time-varying covariates and mediating factors explain about one quarter of the effect of the effect of 2012 (vs. 2007) on daily consumption of fruit, but otherwise those factors explain little of the effects of the full crisis and recovery period on health-promoting behaviors (Row $5 b$ ).

Fruit consumption is the only health-promoting behavior for which we have available pre-crisis trend data. Like sweets, consumption of fruit had also been increasing during the pre-crisis years, but even more dramatically. Annual consumption of fruit increased by $3.5 \%$ per year before the boom and $8.8 \%$ per year during the boom, but decreased by $4.9 \%$ per year during the crisis and then increased by $5 \%$ per year during the recovery (Figure 8). We found that the likelihood of consuming fruit daily decreased substantially during the crisis years (in the range of 3.6 to $5.1 \%$ per year, depending on which model is considered) and then rose by about $7-8 \%$ per year during the recovery. Overall, it appears that, like for smoking and sweets, the crisis induced a short term response in terms of fruit consumption that quickly reverted back to its post-crisis trajectory. In contrast, for alcohol (the only other behavior 
for which we have information on pre-crisis trends) the crisis appeared to induce a change in the direction of the trajectory.

Finally, we estimated supplementary models that limited the sample to individuals who were of working age (between 25 and 61 years old), the group that should be most affected by changes in employment and for whom the 2-3 years of aging between survey waves should not have large average effects on health behaviors, as well as models that used a pooled probit specification that included controls for 2007 age, 2007 age squared, sex, and 2009 education. The results for the former, which are shown in Appendix Tables 5 and 6, are generally similar to those in Tables 2 and 3, suggesting that the aging of the main sample is not confounding our estimates. The results for the latter, which are shown in Appendix Tables 7 and 8, are quite similar to those from the fixed-effects models, providing a robustness check vis-à-vis functional form. In addition, these models indicate that while age is a significant determinant of many of the behaviors, controlling for age in the models does not substantively change the estimated effects of the year indicators, further suggesting that the estimated effects of the crisis in our fixed-effects models in Tables 2 and 3 are not substantially confounded by the aging of the sample by $2-5$ years.

\section{Effects in Context}

We found little evidence that the observed effects of the crisis on most health behaviors operated through individual-level changes in hours worked (or alternatively, employment), real household income, or mental health, although all of these were strongly affected by the crisis. We therefore consider the potential role of more general aspects of the Icelandic economic crisis that may underlie the observed effects. A very prominent aspect of this particular crisis involved prices. Currency fluctuations have always had a major impact on the lives of Icelanders, who live in a country with a small 
open economy that relies heavily on imported goods and has its own currency. ${ }^{14}$ Table 4 summarizes the relevant price changes over the observation period of our study. We used data that are available from official statistics from Iceland for overall prices, as well as for prices of tobacco, alcohol, sweets, soft drinks, and fruit. Prices for fish oil products were collected directly from the Icelandic company Lysi Ltd., which is the manufacturer of the fish oils sold in Iceland; these figures are wholesale prices of $240 \mathrm{ml}$ bottles of cod oil, which is the main fish oil sold as a consumer product.

Overall prices increased by over $27 \%$ between 2007 and 2009, and by over $43 \%$ between 2007 and 2012. Except for fish oil, prices of all of the health-related goods in Table 4 increased by more than the overall price level between 2007 and 2009, a finding that is consistent with the declines in consumption of those goods during that period. The increased consumption of fish oil is also consistent with the decreased price of that good. Between 2009 and 2012, the prices of alcohol and tobacco increased by slightly more than the price level overall, while prices of sweets, soft drinks, and fruit increased by somewhat less than overall prices. In terms of direction, our findings for the period between 2009 and 2012 are consistent with the observed price changes, except in the cases of soft drinks and fish oil, which had changes in consumption directly related to changes in price. Specifically, the consumption of soft drinks fell while the relative price fell and consumption of fish oil rose while its relative price rose. Overall, it appears that price changes explain at least some of the changes in consumption of most health-related goods, but that other demand-related factors, such as tastes and preferences, appear to be important.

Anecdotes exist about Icelanders reassessing their values and going "back to basics" as a result of the crisis. For example, there reportedly has been a return to the hobby of knitting traditional Icelandic sweaters (Helgadóttir, 2011; Mingels, 2014), increased attention to the importance of local community ties rather than material success (Willson \& Gunnlaugsdóttir, 2014), and an increase in

${ }^{14}$ The value of Iceland's imports is about half that of the country's GDP. Source: http://data.worldbank.org/indicator/NE.IMP.GNFS.ZS Accessed on January 3, 2015. 
community participation (Guðbjörnsdóttir \& Davíðsdóttir, 2014). For most of the health-compromising behaviors, we would expect that a "back to basics" movement would result in decreased consumption between 2009 and 2012. However, it is not clear that this would be the case for sweets, as a back-tobasics phenomenon could include home production of sweets such as candies or baked goods. As far as health-promoting behaviors, we would expect the perceived change in values to lead to increases in consumption. Between 2009 and 2012, consumption of fruit, fish oil, and vitamins increased, providing some first-order support for the back to basics hypothesis. However, we did not find increases in recommended sleep, and in supplementary analyses using responses to survey questions how many hours per week individuals spend visiting with family or friends and engaging in arts and crafts, we found no evidence of increases between 2009 and $2012 .^{15}$

\section{Conclusion}

In this study, we used individual-level longitudinal data from Iceland, a country that has experienced a partial recovery from a severe economic crisis, to investigate the extent to which the effects of a recession on a large set of health behaviors are lingering or short-lived and to explore trajectories in health behaviors from pre-crisis boom, to crisis, to recovery.

All of the health-compromising behaviors examined (smoking, heavy drinking, sugared soft drinks, sweets, fast food, and tanning) declined during the crisis, and all of those other than sweets continued to decline during the recovery. For health-promoting behaviors, the patterns varied considerably by behavior. Fruit consumption declined during the crisis, but sharply reversed course during the recovery to exceed its pre-crisis level. Fish oil consumption increased during the crisis and kept increasing during the recovery. Vitamin/mineral consumption did not change during the crisis, but increased during the recovery. Recommended sleep increased during the crisis, but reverted back to its

\footnotetext{
${ }^{15}$ The questions about amount of time individuals spend visiting with family or friends and engaging in arts and crafts were asked in 2009 and 2012, but not in 2007. It is possible that there were increases in these activities immediately following the crisis in 2008.
} 
pre-crisis level during the recovery. For smoking, alcohol, sweets, and fruit, we were able to place these changes within the context of pre-crisis trends and found that: (1) Although there were sharp and substantial declines in smoking, sweets, and fruit during the crisis, these behaviors largely resumed their pre-crisis trajectories (a decline for smoking and increases for sweets and fruit), but (2) the crisis led to a sharp reduction in binge drinking, which was opposite in direction from the underlying positive trend for alcohol consumption and which tapered off somewhat but lingered and remained negative during the recovery period. For soft drinks and fast food, we were able to place our estimates only in a much looser context (trends in the U.S.); based on this information, it appears that the crisis effects for these behaviors were short-lived. For tanning, the lack of trend data in concert with the potentially confounding policy effects precludes us from interpreting the large "recovery effects" as evidence that the crisis had lingering effects on that health behavior.

We found little evidence that the observed effects of the crisis on most health behaviors operated through individual-level changes in hours worked (or alternately, employment), real household income, or mental health, although all of these were strongly affected by the crisis. These factors, together, appeared to play the strongest mediating roles for smoking, sweets, fast food, and fruit, but even for these behaviors, substantial proportions of the crisis and recovery effects remained unexplained. Prices appear to be an important mechanism underlying the observed crisis and recovery effects in Iceland, and there is anecdotal evidence of a national shift toward a more basic lifestyle that may also play a role and warrants further exploration.

It is difficult to reconcile our findings from the past literature on the effects of recessions on health behaviors for several reasons. As indicated earlier: (1) The pre-Great Recession literature reveals no consistent directional relationships between recessions and any health behavior. (2) The Great Recession was distinctive in terms of its severity, and it is not clear that findings vis-à-vis health and health behaviors from studies of business cycles or less severe recessions would be relevant in that 
context. (3) The literature on health behaviors in the context of the Great Recession is small and quite specific (e.g., Barrett \& O'Sullivan (2013) focused on a specific age group (50+) and Antillón, Lauderdale \& Mullahy (2014) focused on quality of sleep as opposed to optimal sleep), with very few studies on any one behavior. (4) No previous study has looked at recovery after recession for the same individuals. Studies of the Great Recession have specifically focused on effects of the recession, and studies of business cycles have implicitly treated upswings and downswings as symmetrical, not allowing for recovery after recession to have different impacts than recession after boom. In our study, we observed all respondents during both the crisis and the subsequent recovery.

All of that said, our findings for the effects of the crisis are largely consistent with those of Compton et al. (2014), which found positive associations between individuals' employment status and both alcohol and tobacco use during the Great Recession in the U.S., and Colman and Dave (2014), which found that job loss led to decreased fast food consumption over years spanning the Great Recession (our smoking results are not directly comparable to those of Colman and Dave). However, they stand in contrast to findings of Latif (2014), which used Canadian panel data from 1994 to 2009 (a period that only marginally intersected with the Great Recession) and found that higher provincial unemployment rates were associated with more binge drinking, but had no impact on the probability of being a smoker. Finally, our findings for 2007-2009 are clearly consistent with those of Ásgeirsdóttir et al. (2014), which were based on the same data and largely the same health behaviors. As far as we know, there are no previous studies of longer-term effects of economic crisis or effects of recovery from deep crisis to which to relate our findings.

As discussed above, although there were strong crisis effects on behaviors, most behaviors reverted back to their pre-crisis levels or trajectories during the recovery. These short-term deviations from previous levels and trends were probably too short-lived to have major impacts on health or mortality. If smoking, soft drinks, sweets, fast food, fruit, fish oil, or sleep (all behaviors with significant 
crisis effects that appear to have moderated as economy recovered) ${ }^{16}$ are important pathways between recessions and health or mortality, our results suggest that this would be the case only in situations that do not rebound as quickly as in Iceland or perhaps in places that have more limited economic and social safety nets than in Iceland. Our findings for alcohol are more suggestive of a health behavior underlying some of the relationship between recessions and health or mortality. Alcohol consumption in Iceland declined dramatically during the crisis years, continued to fall (at a slower rate) during the recovery, and did not revert back to the pre-crisis upward trend during the observation period. Given these lingering effects, which directionally run counter to the pre-crisis upward trend, the results from this study suggest that alcohol is a potential pathway by which recessions could improve health (through reductions in alcohol-related morbidity) or reduce mortality (through reduced morbidity or alcoholinduced accidents). Future research is needed to explore the role of alcohol in the recession-health relationship in other contexts.

\footnotetext{
${ }^{16}$ The longer-term effects of the crisis on tanning are unclear because of the potentially confounding policy changes discussed earlier.
} 


\section{References}

Ahn, T. (2013). Reduction of working time: Does it lead to a healthy lifestyle? School of Economics, Sogang University. Accessed on December 14, 2014 from http://www.sole-jole.org/14105.pdf

Antillón, M., Lauderdale, D. S., \& Mullahy, J. (2014). Sleep behavior and unemployment conditions. Economics \& Human Biology, 14, 22-32.

Ásgeirsdóttir, T., Corman, H., Noonan, K., Ólafsdóttir, D., \& Reichman, N. (2014). Was the economic crisis of 2008 good for Icelanders? Impact on health behaviors. Economics and Human Biology, 13, 119.

Ball, L. M. (2014). Long-Term Damage from the Great Recession in OECD Countries (No. w20185). National Bureau of Economic Research.

Barrett, A., \& O'Sullivan, V. (2013). A short note on the wealth, health and wellbeing of Ireland's older people before and during the economic crisis. SHARE Working Paper (15-2013). Economic and Social Research Institute.

Böckerman, P., \& Ilmakunnas, P. (2009). Unemployment and self-assessed health: Evidence from panel data. Health Economics, 18(2), 161-179.

Burgard, S. A., Ailshire, J. A., \& Kalousova, L. (2013). The Great Recession and health: People, populations, and disparities. The ANNALS of the American Academy of Political and Social Science, 650(1), 194-213.

Catalano, R., Goldman-Mellor, S., Saxton, K., Margerison-Zilko, C., Subbaraman, M., LeWinn, K., \& Anderson, E. (2011). The health effects of economic decline. Annual Review of Public Health, 32, 431-450.

Colman, G. \& D. Dave (2014). Unemployment and health behaviors over the business cycle: a longitudinal view. (No. w20748) National Bureau of Economic Research.

Compton, W. M., Gfroerer, J., Conway, K. P., \& Finger, M.S. (2014). Unemployment and substance outcomes in the United States 2002-2010. Drug and Alcohol Dependence, 142, 350-353.

Dugan, A. (2013) Fast food still major part of U.S. diet. Accessed on February 3, 2014 from: http://www.gallup.com/poll/163868/fast-food-major-part-diet.aspx.

Granados, J. A. T., House, J. S., Ionides, E. L., Burgard, S., \& Schoeni, R. S. (2014). Individual joblessness, contextual unemployment, and mortality risk. American Journal of Epidemiology, 180(3), 280287.

Greenstein, T. (2013, February 20). Iceland's stabilized economy is a surprising success story. Accessed on December 11, 2014 from:

http://www.forbes.com/sites/traceygreenstein/2013/02/20/icelands-stabilized-economy-is-asurprising-success-story/.

Grønn, A. \& Fredholm, M. (2013). Baltic and Icelandic Experiences of Capital Flows and Capital Flow Measures . International Monetary Fund: Working Paper https://www.imf.org/external/pubs/ft/wp/2013/wp13242.pdf (Accessed on October 20, 2014).

Guðlaugsson, J. O., Magnússon, K. T., \& Jónsson, S. H. (2014). Heilsa og líđan Íslendinga 2012: Framkvæmdaskýrsla (Health and Wellbeing of Icelanders 2012. Project Report). Reykjavík: Embætti Landlæknis (Directorate of Health). Accessed on January 18, 2015 from: http://www.landlaeknir.is/servlet/file/store93/item22830/Framkvaemdaskyrsla 2012 loka.pdf.

Guðmundsson, M. (2013). Iceland's crisis and recovery and current challenges. Accessed on October 14, 2014 from: http://www.bis.org/review/r130312d.pdf.

Guðbjörnsdóttir,G.S. \& Davíđsdóttir, S. (2014). Schools in two communities weather the crash. Gambling debt: Iceland's rise and fall in the global economy. Edited by E. Paul Durrenberger and Gísli Pásson. University Press of Colorado: Boulder, p. 163-174. 
Helgadóttir, G. (2011). Nation in a sheep's coat: The Icelandic sweater. FORMakademisk, 4 (2), 59-68. Accessed on February 2, 2015 from:

https://journals.hioa.no/index.php/formakademisk/article/viewFile/201/210.

Jeppesen, C., Bjerregaard, P. \& Young, K. (2011). Food-based dietary guidelines in circumpolar regions. Circumpolar Health Supplements 8. Accessed on October 14, 2014 from: http://www.circumpolarhealthjournal.net/public/journals/32/chs/CHS 2011 8.pdf

Jónsson, S.H., Guðlaugsson, J.O., Gylfason, H.F. \& Guðmundsdóttir, D.G. (2011). Heilsa og líđan Íslendinga 2007: Framkvæmdaskýrsla (Health and Wellbeing of Icelanders 2007. Project Report). Reykjavík: Lýðheilsustöð (The Public Health Institute of Iceland). Accessed on January 18, 2015 from:

http://www.landlaeknir.is/servlet/file/store93/item11019/Heilsa.og.lidan.Islendinga.2007.Fram kvaemdaskyrsla.pdf.

Kallestrup, R. (2007). The volatility of the Icelandic króna. Central Bank of Iceland: Monetary Bulletin, 2008(1), 101-112.

Kit, B. K., Fakhouri, T. H., Park, S., Nielsen, S. J., \& Ogden, C. L. (2013). Trends in sugar-sweetened beverage consumption among youth and adults in the United States: 1999-2010. The American Journal of Clinical Nutrition, ajcn-057943.

Køster, B., Thorgaard, C., Philip, A., \& Clemmensen, I.H. (2011), Sunbed use and campaign initiatives in the Danish population, 2007-2009: a cross-sectional study. Journal of the European Academy of Dermatology and Venereology, 25: 1351-1355.

Latif, E. (2014). The impact of recession on drinking and smoking behaviours in Canada. Economic Modelling, 42, 43-56.

Lustig, R.H., Schmidt, L.A., Brindis, C.D. (2012). Public health: The toxic truth about sugar. Nature, 482, 27-29.

Mayo Clinic (2015). Drugs and Supplements: Omega-3 fatty acids, fish oil, alpha-linolenic acid. Accessed on January 14, 2015 from: http://www.mayoclinic.org/drugs-supplements/omega-3-fatty-acidsfish-oil-alpha-linolenic-acid/background/hrb-20059372.

Mclnerney, M., \& Mellor, J. M. (2012). Recessions and seniors' health, health behaviors, and healthcare use: Analysis of the Medicare Current Beneficiary Survey. Journal of Health Economics, 31(5), 744-751.

Mingels, G. (2014, January 10). Out of the abyss: Looking for lessons in Iceland's recovery. Accessed on December 11, 2014 from: http://www.spiegel.de/international/europe/financial-recovery-of-iceland-a-case-worthstudying-a-942387.html.

Modrek, S., Stuckler, D., McKee, M., \& Cullen, M. R. (2013). A review of health consequences of recessions internationally and a synthesis of the US response during the Great Recession. Public Health Reviews, 35(1), 1-33.

Ólafsdóttir, K. \& Einarsdóttir, A. (2013). From Recession to Growth-Recovery in the labor market. Working Paper. http://www.eaepeparis2013.com/papers/Full Paper Katrin-Olafsdottir.pdf.

Ruhm, C.J. (2000). Are recessions good for your health? The Quarterly Journal of Economics, 115 (2), 617-650.

Ruhm, C. J. (2013). Recessions, healthy no more? (No. w19287). National Bureau of Economic Research.

Smith, L. P., Ng, S. W., \& Popkin, B. M. (2014). Resistant to the recession: Low-income adults' maintenance of cooking and away-from-home eating behaviors during times of economic turbulence. American Journal of Public Health, 104(5), 840-846.

Tekin, E., McClellan, C., \& Minyard, K. J. (2013). Health and health behaviors during the worst of times: Evidence from the Great Recession (No. w19234). National Bureau of Economic Research. 
Toffolutti, V., \& Suhrcke, M. (2014). Assessing the short term health impact of the Great Recession in the European Union: a cross-country panel analysis. Preventive Medicine, 64, 54-62.

Urbanos-Garrido, R. M., \& López-Valcárcel, B. G. (2014). The influence of the economic crisis on the association between unemployment and health: an empirical analysis for Spain. The European Journal of Health Economics, 1-10.

U.S. Centers for Disease Control and Prevention, 2013. Indoor tanning Accessed on January 23, 2013 from: http://www.cdc.gov/cancer/skin/basic info/indoor tanning.htm.

U.S. Centers for Disease Control and Prevention, 2012. Sleep and sleep disorders. Accessed on March 20, 2012 from: http://www.cdc.gov/Features/Sleep/.

van Gool, K., \& Pearson, M. (2014). Health, austerity and economic crisis: Assessing the short-term impact in OECD countries." OECD Health Working Papers, No. 76, OECD Publishing.

Willson and Gunnlaugsdóttir (2014). The resilience of rural Iceland. Gambling debt: Iceland's rise and fall in the global economy. Edited by E. Paul Durrenberger and Gísli Pásson. University Press of Colorado: Boulder, p. 137-150.

World Bank. (2014a). World development indicators-Google public data explorer. Accessed on December 11, 2014 from:

http://www.google.com/publicdata/explore?ds=d5bncppjof8f9 \&met y=ny gdp mktp kd zg\& idim=country:USA:IND:GBR\&hl=en\&dl=en\#!ctype=I\&strail=false\&bcs=d\&nselm=h\&met $y=n y \quad g$ dp mktp kd zg\&scale $y=$ lin\&ind $y=$ false\&rdim=region\&idim=country:USA:IND:GBR:ISL:ESP:IRL \&ifdim=region\&hl=en US\&dl=en\&ind=false.

World Bank. (2014b). World Databank. Unemployment, total (\% of total labor force) (modeled ILO estimate). Accessed on December 11, 2014 from:

http://data.worldbank.org/indicator/SL.UEM.TOTL.ZS?order=wbapi data value 2007+wbapi d ata value\&sort=asc\&page $=1$. 
Figure 1: Annual GDP Growth in Iceland (based on constant local currency), 2000-2013

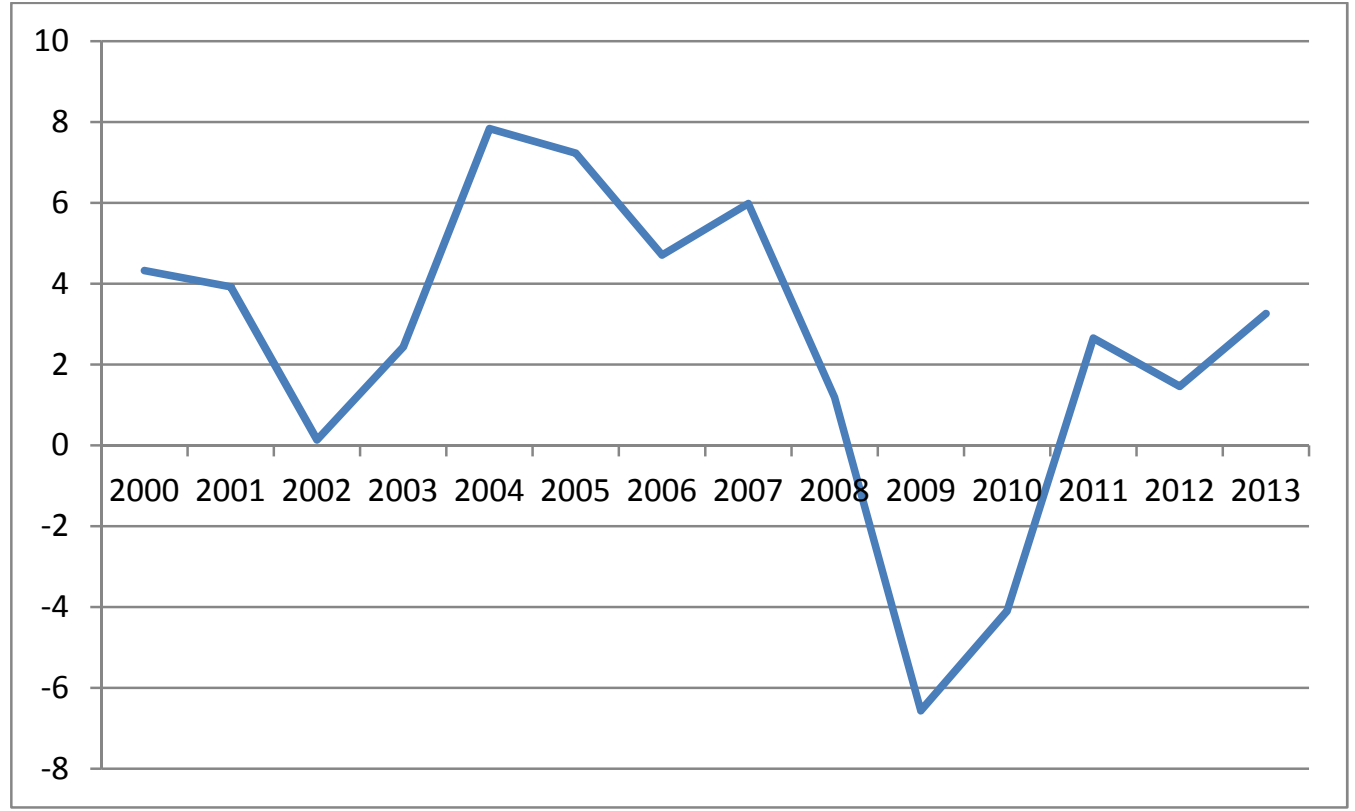

Source: World Bank. Accessed on January 20, 2015 from:

http://data.worldbank.org/indicator/NY.GDP.MKTP.KD.ZG/countries?cid=GPD 30\&display=default

Figure 2: Annual Unemployment Rate in Iceland 2000-2014

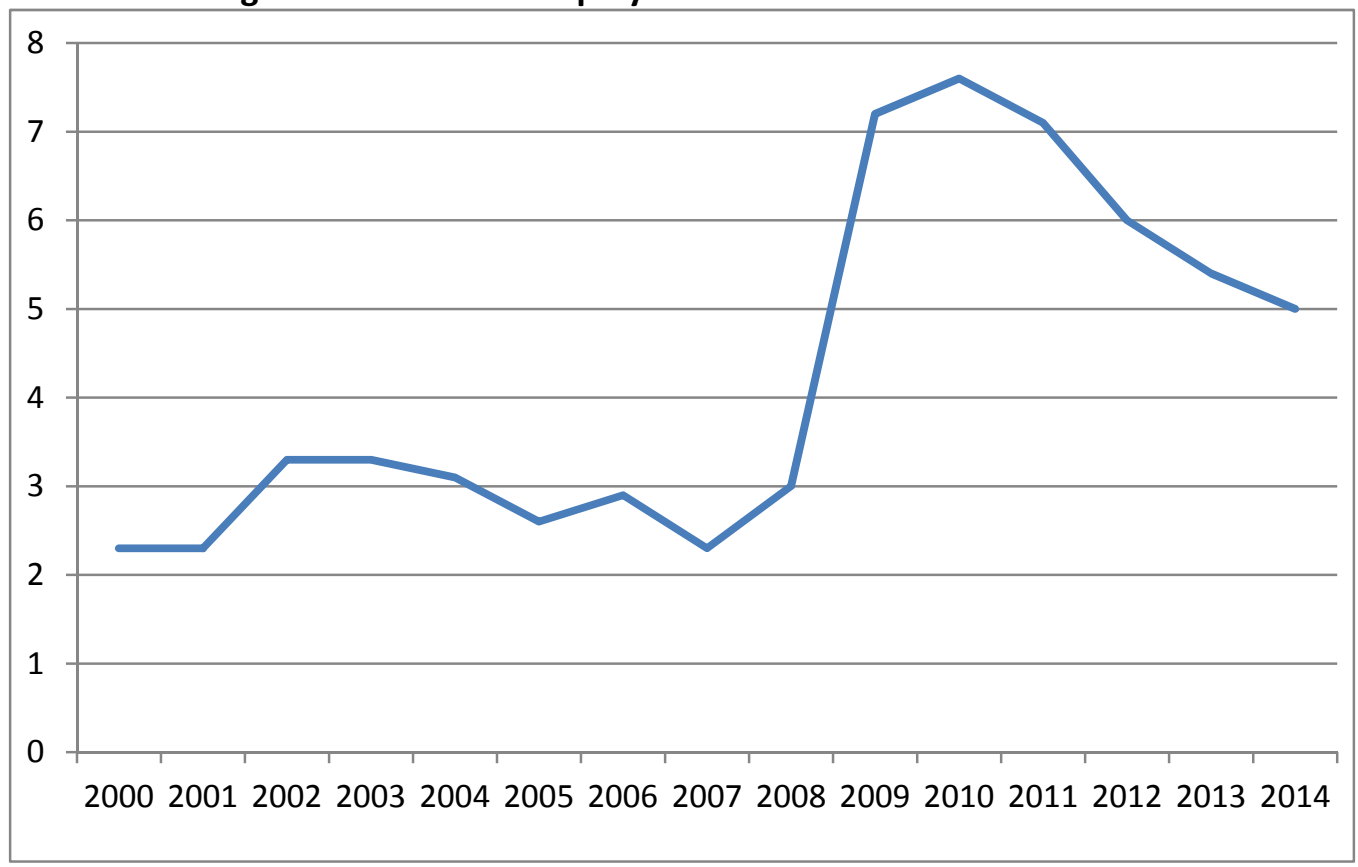

Source: Statistics Iceland. Accessed on January 29, 2015 from:

Error! Hyperlink reference not valid. 
Figure 3: Consumer Price Index Annual Changes in Iceland 2000-2014

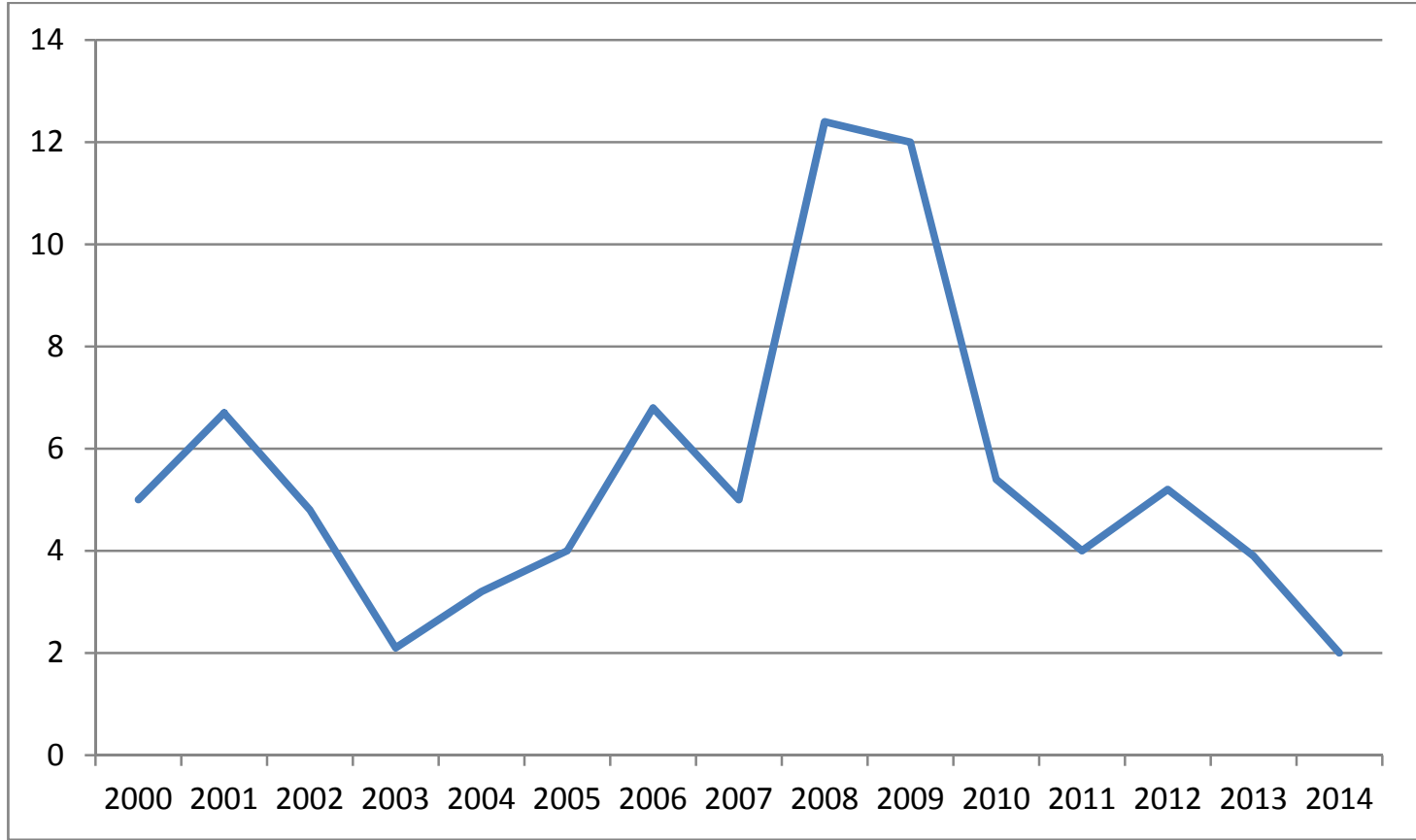

Source: Statistics Iceland. Accessed on January 20, 2015 from:

http://www.statice.is/?PagelD=2932\&src=https://rannsokn.hagstofa.is/pxen/Dialog/varval.asp?ma=VIS01000\%26ti=Changes+i n+the+consumer+price+index+from+1988\%26path=../Database/visitolur/neysluverd/\%26lang=1\%26units=Indices\%20and\%20a nnualized\%20rates

Figure 4: Annual Average Real Wage Index in Iceland 2000-2013

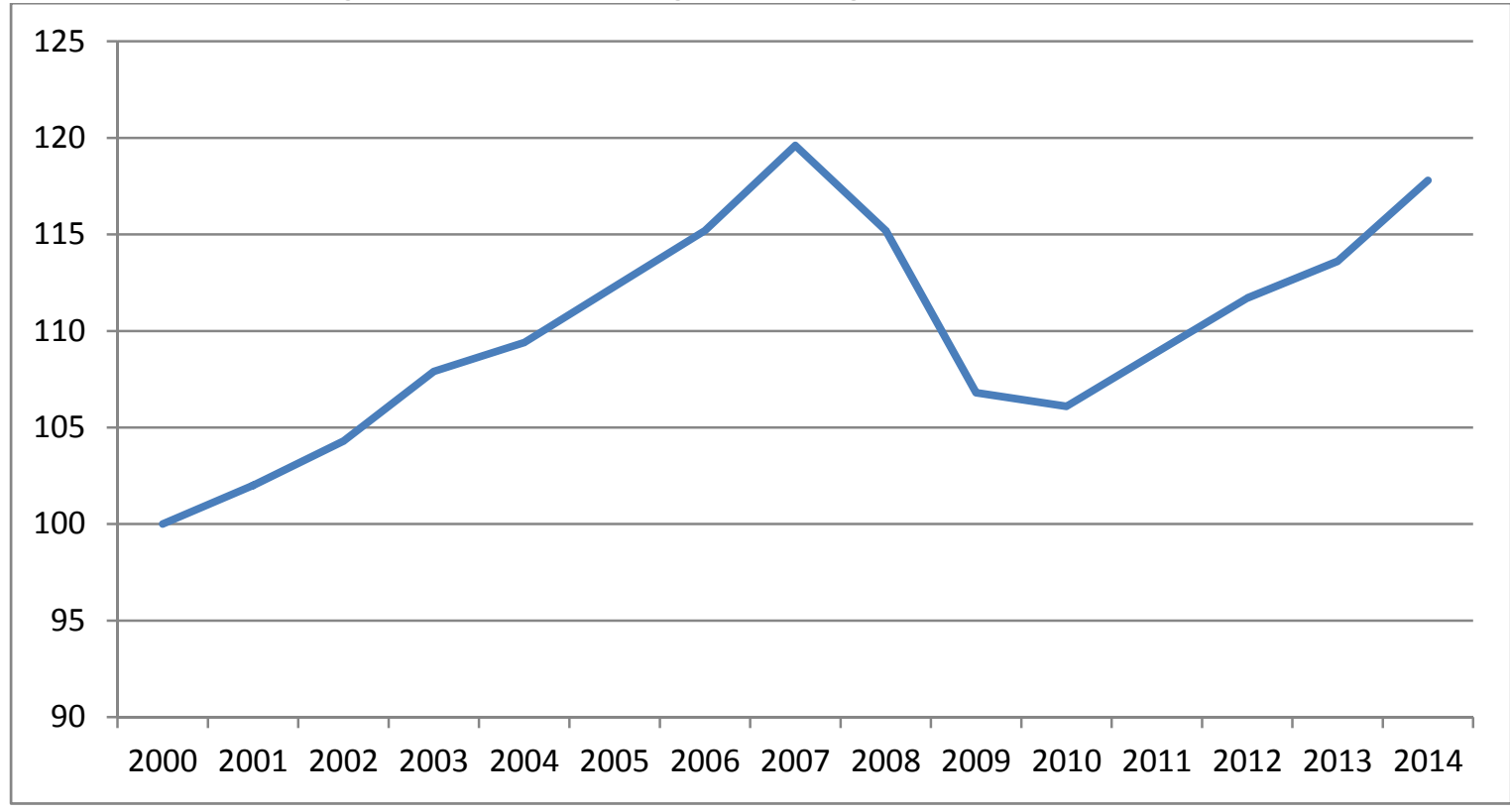

Source: Statistics Iceland. Accessed on January 29, 2015 from:

http://www.statice.is/?PagelD=1251\&src=https://rannsokn.hagstofa.is/pxen/Dialog/varval.asp?ma=VIS04004\%26ti=Real+wage s\%2C+index+1989-

2014+++++++++++++++++++++++++++++++++++++++++++\%26path=../Database/visitolur/launavisitala/\%26lang=1\%26units=Ind ex/percent 
Figure 5: Percentage of Icelanders Age 18+ Who Smoke Every Day

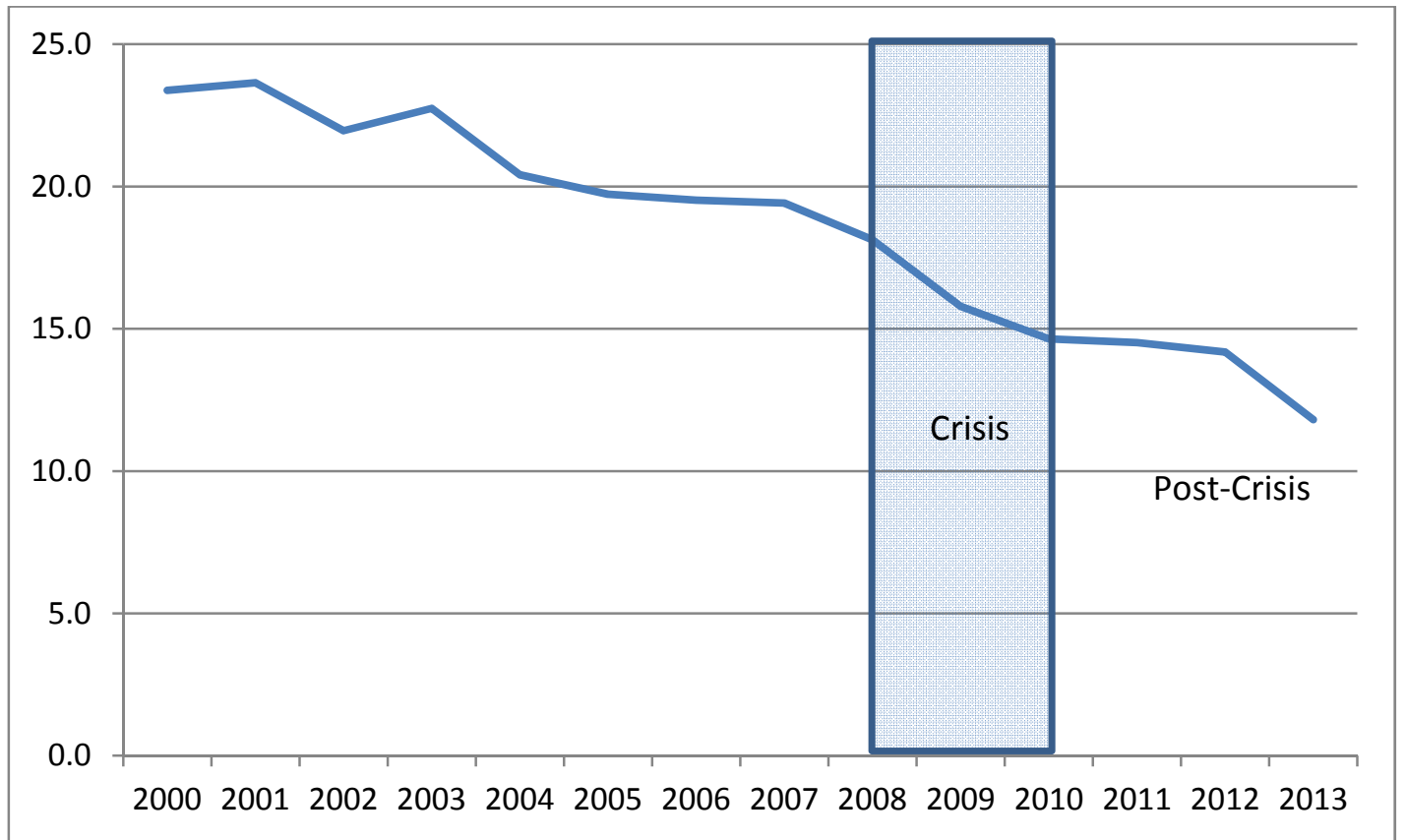

Source: Directorate of Health in Iceland. Accessed January 30, 2015 from: http://www.landlaeknir.is/tolfraedi-og-rannsoknir/tolfraedi/allt-talnaefni/

Figure 6: Alcohol Sales Per Capita Age 15+ (Liters of Pure Alcohol)

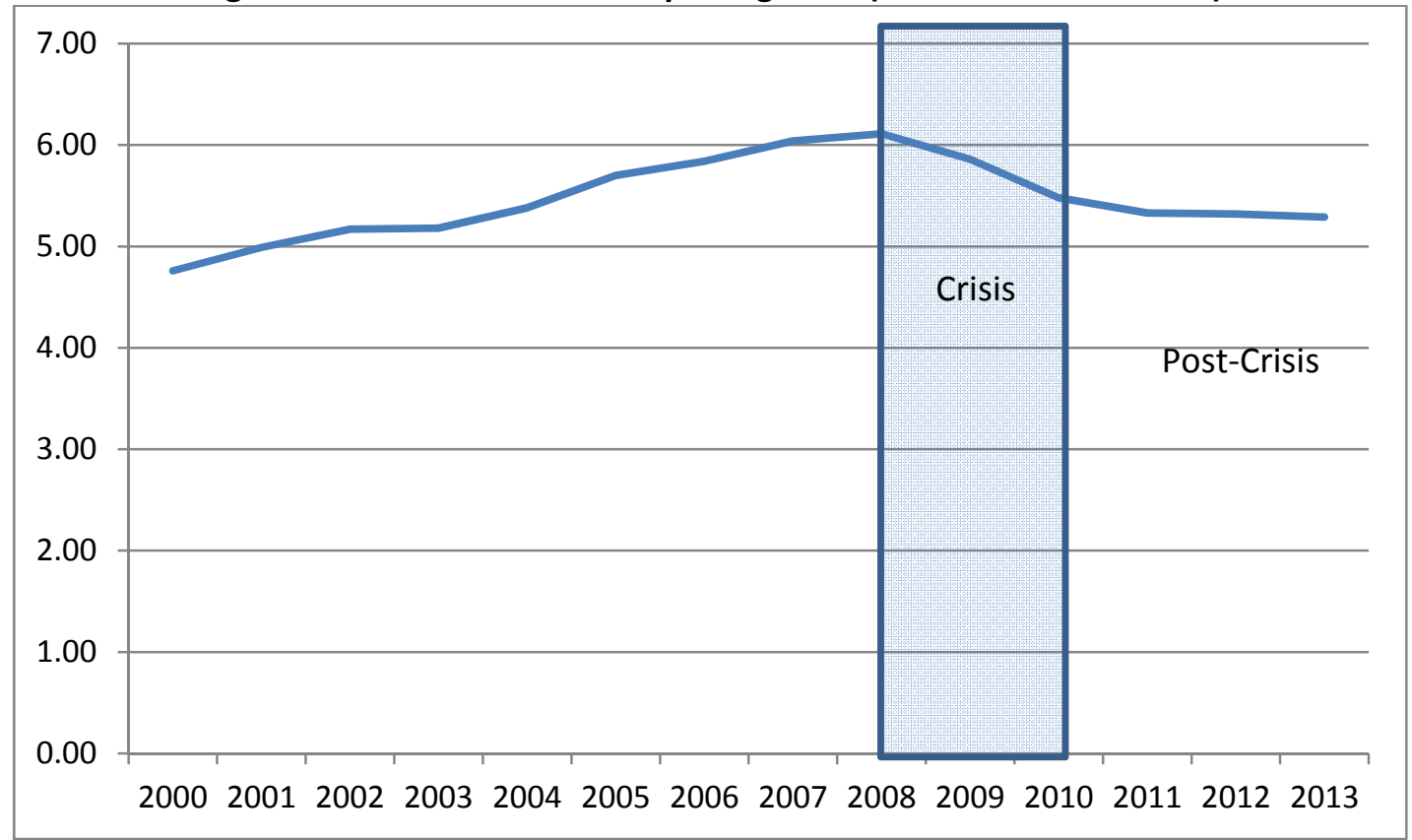

Source: Directorate of Health in Iceland. Accessed January 30, 2015 from:

http://www.landlaeknir.is/tolfraedi-og-rannsoknir/tolfraedi/allt-talnaefni/ 
Figure 7: Per Capita Annual Consumption of Sweets, kg/person/year

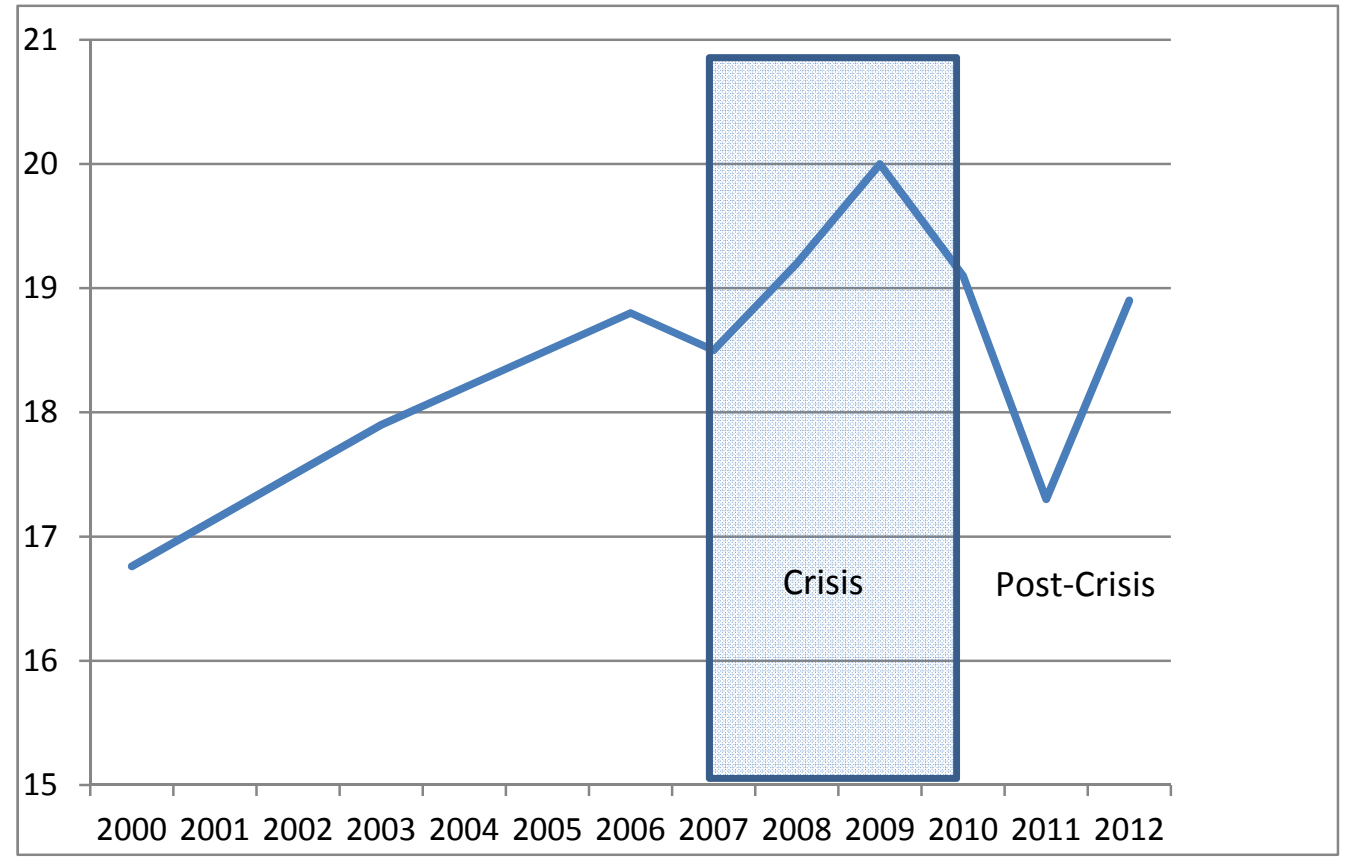

Source: Directorate of Health in Iceland. Accessed on January 20, 2014 from: http://www.landlaeknir.is/tolfraedi-ogrannsoknir/tolfraedi/allt-talnaefni/

Figure 8: Annual Fruit Consumption in Iceland, kg per Capita

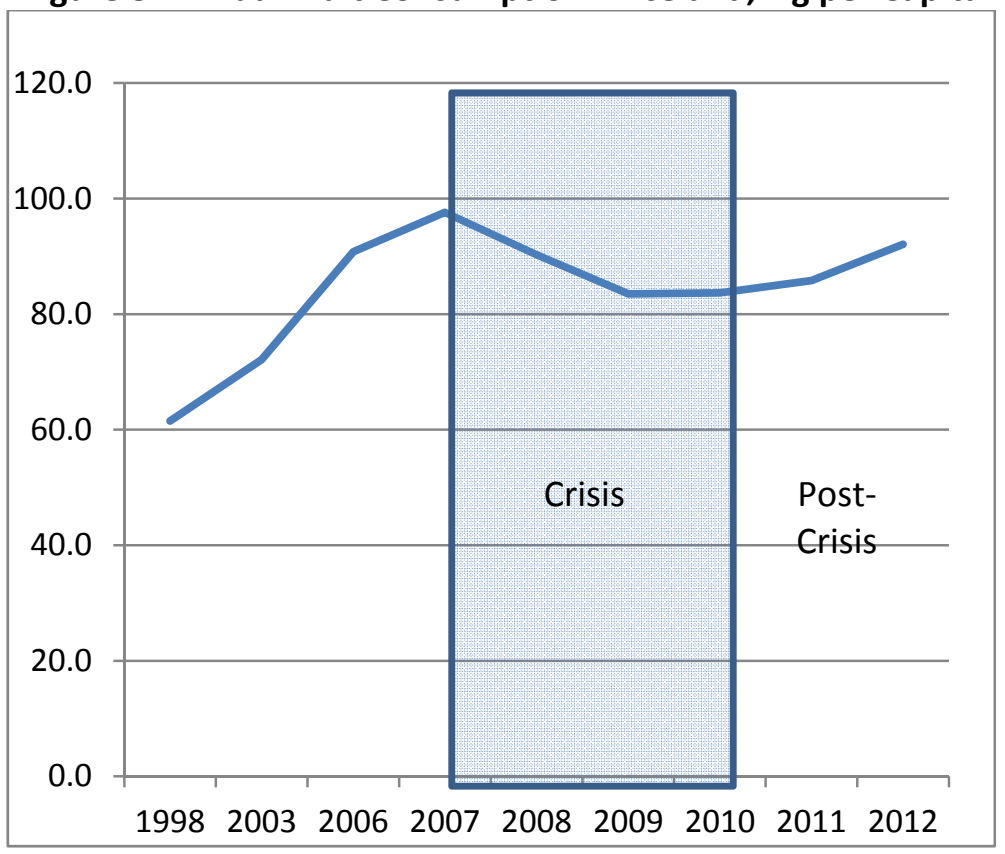

Sources:

1998-2010: The Directorate of Health Institute in Iceland. Accessed on January 20, 2015 from: http://www2.lydheilsustod.is/rannsoknir/matur-mataraedi-holdafar/frambod-og-sala-a-matvoru/nr/2905 2011-2012: The Directorate of Health Institute in Iceland. Accessed on January 20, 2014 from: http://www.landlaeknir.is/tolfraedi-og-rannsoknir/tolfraedi/allt-talnaefni/ 


\begin{tabular}{|c|c}
\multicolumn{3}{c}{ Full Sample } \\
18-79 years \\
\hline $2007 \quad 2009 \quad 2012$
\end{tabular}

\section{Health-Compromising Behaviors}

Currently smokes cigarettes or other

tobacco product

$5+$ alcoholic drinks in 1 day at least 1

time/month (past year)

Daily sugared soft drink

Daily sweets

Weekly fast food

Indoor tanning (past 12 mos.)

Health-Promoting Behaviors

Cohabiting
.38

.35

.31

.74

.09

.09

.34

.21

.18

.11

.35

.43

.40

.47

.31

.38

.77

.75

.50

.55

.57

.24

.21

.20

.26

.24

.23

.44

.44

.44

.28

.25

.24

.10

.10

.11

.78

.78

.79
Daily fruit

Daily fish oil

Daily vitamins

Gets recommended sleep (7-9

hours/night)

Time-Varying Covariates

Married

Neither married nor cohabiting

Child(ren) in household

Lives with adult other than partner

Lives in rural area

Homeowner

.38

.34

.32

$(73$

.73

.77

.74

Potential Mediators 
Hours of work, mean

Currently working

Real household income (millions of 2007

krona/year), mean

Anxiety or poor mental health
30.5

.83

7.0

.27
28.8

.79

5.6

.30
29.7

.79

5.9

.29
35.3

.91

7.6

6.1

6.3

Notes: Full sample includes respondents who participated in all three interviews (2007, 2009, and 2011), had non-missing data on time-varying covariates and potential mediators, and, for the health behavior means, had non-missing data for the particular behavior. Exchange rate was about 125 krona to the U.S. dollar at the end of November 2012. Source: http://www.cb.is/exchange-rate/ (accessed on January 20, 2015). Thus, 1 million krona translates to about $\$ 8,000$ U.S. 
Table 2: Short- and Longer-Term Effects of Economic Crisis in Iceland on Health-Compromising Behaviors-Fixed-Effects Models

\begin{tabular}{|c|c|c|c|c|c|c|}
\hline & Smoking & $\begin{array}{c}\text { Heavy } \\
\text { Drinking }\end{array}$ & $\begin{array}{c}\text { Daily } \\
\text { Sugared } \\
\text { Soft Drink } \\
\end{array}$ & $\begin{array}{c}\text { Daily } \\
\text { Sweets }\end{array}$ & $\begin{array}{c}\text { Weekly } \\
\text { Fast Food }\end{array}$ & $\begin{array}{l}\text { Indoor } \\
\text { Tanning }\end{array}$ \\
\hline \multicolumn{7}{|l|}{ Full sample } \\
\hline \multicolumn{7}{|l|}{ 1. No covariates } \\
\hline a. Effect of 2009 indicator & $-0.032 * * *$ & $-0.011^{*}$ & $-0.011 * * *$ & $-0.011^{* *}$ & $-0.028 * * *$ & $-0.029 * * *$ \\
\hline b. Effect of 2012 indicator & $-0.043 * * *$ & $-0.018 * * *$ & $-0.014 * * *$ & 0.003 & $-0.034 * * *$ & $-0.064 * * *$ \\
\hline $\begin{array}{l}\text { c. } p \text {-value for difference } \\
\text { between } 2009 \text { and } 2012\end{array}$ & 0.012 & 0.406 & 0.347 & 0.001 & 0.522 & 0.000 \\
\hline $\mathbf{N}$ (person years) & 9,381 & 9,396 & 9,447 & 9,464 & 9,509 & 9,099 \\
\hline \multicolumn{7}{|l|}{ Analysis sample, with: } \\
\hline \multicolumn{7}{|l|}{ 2. No covariates } \\
\hline a. Effect of 2009 indicator & $-0.029 * * *$ & $-0.021 * *$ & -0.012 & $-0.022 * * *$ & $-0.053^{* * *}$ & $-0.032 * * *$ \\
\hline b. Effect of 2012 indicator & $-0.049 * * *$ & $-0.039 * * *$ & $-0.026 * * *$ & -0.008 & $-0.072 * * *$ & $-0.101^{* * *}$ \\
\hline $\begin{array}{l}\text { c. } p \text {-value for difference } \\
\text { between } 2009 \text { and } 2012\end{array}$ & 0.008 & 0.060 & 0.076 & 0.099 & 0.099 & 0.000 \\
\hline \multicolumn{7}{|l|}{ 3. Time-varying covariates } \\
\hline a. Effect of 2009 indicator & $-0.029 * * *$ & $-0.021 * *$ & $-0.013 *$ & $-0.021 * * *$ & $-0.053 * * *$ & $-0.032 * * *$ \\
\hline b. Effect of 2012 indicator & $-0.048 * * *$ & $-0.036 * * *$ & $-0.027 * * *$ & -0.008 & $-0.071 * * *$ & $-0.100 * * *$ \\
\hline $\begin{array}{l}\text { c. } p \text {-value for difference } \\
\text { between } 2009 \text { and } 2012\end{array}$ & 0.010 & 0.109 & 0.056 & 0.109 & 0.126 & 0.000 \\
\hline \multicolumn{7}{|l|}{$\begin{array}{l}\text { 4. Time-varying covariates } \\
\text { plus mediators }\end{array}$} \\
\hline a. Effect of 2009 indicator & $-0.018^{* *}$ & $-0.021 *$ & -0.010 & $-0.025 * * *$ & $-0.041 * * *$ & $-0.034 * * *$ \\
\hline b. Effect of 2012 indicator & $-0.039 * * *$ & $-0.036 * * *$ & $-0.025 * * *$ & -0.011 & $-0.061 * * *$ & $-0.101 * * *$ \\
\hline $\begin{array}{l}\text { c. } p \text {-value for difference } \\
\text { between } 2009 \text { and } 2012\end{array}$ & 0.010 & 0.098 & 0.055 & 0.101 & 0.109 & 0.000 \\
\hline $\mathbf{N}$ (person years) & 6,438 & 6,495 & 6,498 & 6,486 & 6,555 & 6,111 \\
\hline \multicolumn{7}{|l|}{$\begin{array}{l}\text { 5. \% of change in behavior } \\
\text { explained by time-varying } \\
\text { covariates \& mediators }\end{array}$} \\
\hline a. 2009 v. 2007 & 37.9 & 0.0 & $\mathrm{n} / \mathrm{a}$ & $\mathrm{n} / \mathrm{a}$ & 22.6 & $\mathrm{n} / \mathrm{a}$ \\
\hline b. 2012 v. 2007 & 20.4 & 7.7 & 3.9 & $\mathrm{n} / \mathrm{a}$ & 15.3 & 0.0 \\
\hline c. 2012 v. 2009 & $n / a$ & 16.7 & $n / a$ & 0.0 & $\mathrm{n} / \mathrm{a}$ & 2.9 \\
\hline
\end{tabular}

Notes: Sample weights are applied. Figures for effects of 2009 and 2012 indicators are regression coefficients. Full sample consists of respondents who participated in all three interviews $(2007,2009$, and 2012) and had non-missing data on the outcome, but may or may not have had missing data on right hand variables. Analysis sample consists of respondents completing all 3 interviews who had non-missing data on the outcome and all of the time-varying covariates and potential mediators. Time-varying covariates are married, cohabiting, lives with adult other than partner, lives in rural area, and homeowner. Mediators are hours of work, real income, and anxiety or poor mental health. The percentage of the change in the effects of the crisis that resulted from including the time-varying covariates and mediators is computed by subtracting the coefficient for a given behavior in a given year in Model 2 from the corresponding coefficient in Model 4, dividing by the former, and multiplying by $100 . \mathrm{n} / \mathrm{a}=$ base year coefficient is not statistically significant, so "percent of change" calculation is not meaningful, or coefficient in Panel 4 is larger than coefficient in Panel 2. ${ }^{* * *} p<.10 ;{ }^{* *} p<.05 ;{ }^{*} p<.01$. 
Table 3: Short- and Longer-Term Effects of Economic Crisis in Iceland on Health-Promoting BehaviorsFixed-Effects Models

\begin{tabular}{|c|c|c|c|c|}
\hline & $\begin{array}{l}\text { Daily } \\
\text { Fruit }\end{array}$ & $\begin{array}{c}\text { Daily } \\
\text { Fish Oil }\end{array}$ & $\begin{array}{c}\text { Daily } \\
\text { Vitamins }\end{array}$ & $\begin{array}{c}\text { Recommended } \\
\text { Sleep } \\
\end{array}$ \\
\hline \multicolumn{5}{|l|}{ Full sample } \\
\hline \multicolumn{5}{|l|}{ 1. No covariates } \\
\hline a. Effect of 2009 indicator & $-0.034 * * *$ & $0.035^{* * *}$ & 0.002 & $0.026 * * *$ \\
\hline b. Effect of 2012 indicator & $0.024 * *$ & $0.112^{* * *}$ & $0.084^{* * *}$ & 0.001 \\
\hline $\begin{array}{l}\text { c. } p \text {-value for difference between } \\
2009 \text { and } 2012\end{array}$ & 0.000 & 0.000 & 0.000 & 0.003 \\
\hline $\mathbf{N}$ (person years) & 9,545 & 9,482 & 9,326 & 9,529 \\
\hline \multicolumn{5}{|l|}{ Analysis sample, with: } \\
\hline \multicolumn{5}{|l|}{ 2. No covariates } \\
\hline a. Effect of 2009 indicator & $-0.027^{* *}$ & $0.042^{* * *}$ & 0.002 & $0.028 * *$ \\
\hline b. Effect of 2012 indicator & $0.054^{* * *}$ & $0.117^{* * *}$ & $0.067^{* * *}$ & 0.002 \\
\hline $\begin{array}{l}\text { c. } p \text {-value for difference between } \\
2009 \text { and } 2012\end{array}$ & 0.000 & 0.000 & 0.000 & 0.031 \\
\hline \multicolumn{5}{|l|}{ 3. Time-varying covariates } \\
\hline a. Effect of 2009 indicator & $-0.029 * *$ & $0.045^{* * *}$ & 0.001 & $0.026 * *$ \\
\hline b. Effect of 2012 indicator & $0.049 * * *$ & $0.121^{* * *}$ & $0.066 * * *$ & -0.002 \\
\hline $\begin{array}{l}\text { c. } p \text {-value for difference between } \\
2009 \text { and } 2012\end{array}$ & 0.000 & 0.000 & 0.000 & 0.023 \\
\hline \multicolumn{5}{|l|}{$\begin{array}{l}\text { 4. Time-varying covariates plus } \\
\text { mediators }\end{array}$} \\
\hline a. Effect of 2009 indicator & $-0.039 * * *$ & $0.039 * * *$ & -0.004 & $0.029 * *$ \\
\hline b. Effect of 2012 indicator & $0.041^{* * *}$ & $0.117^{* * *}$ & $0.063 * * *$ & -0.000 \\
\hline $\begin{array}{l}\text { c. } p \text {-value for difference between } \\
2009 \text { and } 2012\end{array}$ & 0.000 & 0.000 & 0.000 & 0.018 \\
\hline $\mathbf{N}$ (person years) & 6,522 & 6,462 & 6,333 & 6,507 \\
\hline \multicolumn{5}{|l|}{$\begin{array}{l}\text { 5. \% of change in behavior } \\
\text { explained by time-varying } \\
\text { covariates \& mediators }\end{array}$} \\
\hline a. 2009 v. 2007 & $n / a$ & 7.1 & $\mathrm{n} / \mathrm{a}$ & $\mathrm{n} / \mathrm{a}$ \\
\hline b. 2012 v. 2007 & 24.1 & 0.0 & 6.0 & $\mathrm{n} / \mathrm{a}$ \\
\hline c. 2012 v. 2009 & 1.2 & $\mathrm{n} / \mathrm{a}$ & $n / a$ & $\mathrm{n} / \mathrm{a}$ \\
\hline
\end{tabular}

Notes: Sample weights are applied. Figures for effects of 2009 and 2012 indicators are regression coefficients. Full sample consists of respondents who participated in all three interviews $(2007,2009$, and 2012) and had non-missing data on the outcome, but may or may not have had missing data on right hand variables. Analysis sample consists of respondents completing all 3 interviews who had non-missing data on the outcome and all of the time-varying covariates and potential mediators. Time-varying covariates are married, cohabiting, lives with adult other than partner, lives in rural area, and homeowner. Mediators are hours of work, real income, and anxiety or poor mental health. The percentage of the change in the effects of the crisis that resulted from including the time-varying covariates and mediators is computed by subtracting the coefficient for a given behavior in a given year in Model 2 from the corresponding coefficient in Model 4, dividing by the former and multiplying by 100. na = base year coefficient is not statistically significant, so "percent of change" calculation is not meaningful, or coefficient in Panel 4 is larger than coefficient in Panel 2. ${ }^{* *} p<.10 ;{ }^{* *} p<.05 ;{ }^{*} p<.01$. 
Table 4: Price changes in Iceland

\begin{tabular}{|l|c|c|c|}
\hline & $\begin{array}{c}\text { \% increase between } \\
\mathbf{2 0 0 7} \text { and 2009 }\end{array}$ & $\begin{array}{c}\text { \% increase between } \\
\mathbf{2 0 0 9} \text { and 2012 }\end{array}$ & $\begin{array}{c}\text { \% increase between } \\
\mathbf{2 0 0 7} \text { and 2012 }\end{array}$ \\
\hline Overall & 27.3 & 12.8 & 43.6 \\
\hline Tobacco & 40.4 & 18.3 & 66.2 \\
\hline Alcohol & 48.7 & 13.0 & 68.0 \\
\hline Sweets & 49.9 & 2.2 & 53.2 \\
\hline Soft Drinks & 57.1 & 8.5 & 70.5 \\
\hline Fruit & 91.8 & 6.5 & 104.2 \\
\hline Fish Oil & 21.0 & 26.0 & 52.4 \\
\hline
\end{tabular}

Notes: Source (for all but fish oil): Statistics Iceland. Accessed on January 20, 2015 from:

http://www.statice.is/?PagelD=2932\&src=https://rannsokn.hagstofa.is/pxen/Dialog/varval.asp?ma=VIS

01303\%26ti=Consumer+price+index\%2C+subindices+from+2002\%26path=../Database/visitolur/neysluv erdundir/\%26lang=1\%26units=Indices. Fish oil prices obtained from Lysi Ltd. via personal communication on November 25, 2014. 
Appendix Table 1: Characteristics of 2007 Survey Participants (ages 18-79 years), by Attrition Status

\begin{tabular}{|c|c|c|c|c|}
\hline \multirow{2}{*}{$\begin{array}{l}\text { Sample Characteristics } \\
\text { (measured in 2007) }\end{array}$} & \multicolumn{2}{|c|}{ Weighted } & \multicolumn{2}{|c|}{ Unweighted } \\
\hline & $\begin{array}{c}\text { Leavers } \\
\text { (did not } \\
\text { complete all } 3 \\
\text { interviews) }\end{array}$ & $\begin{array}{c}\text { Stayers } \\
\text { (completed all } \\
3 \text { interviews) }\end{array}$ & $\begin{array}{c}\text { Leavers } \\
\text { (did not } \\
\text { complete all } 3 \\
\text { interviews) }\end{array}$ & $\begin{array}{c}\text { Stayers } \\
\text { (completed } \\
\text { all } 3 \\
\text { interviews) }\end{array}$ \\
\hline Age & $40.07 * * *$ & $41.96 * * *$ & $43.78 * * *$ & $45.30 * * *$ \\
\hline Male & .45 & .43 & .45 & .46 \\
\hline Married & $.41 * * *$ & $.50 * * *$ & $.57 * * *$ & $.63 * * *$ \\
\hline Cohabiting & .22 & .24 & .21 & .19 \\
\hline Child in household & $.38 * * *$ & $.44 * * *$ & .52 & .51 \\
\hline Lives with adult other than partner & $.36 * * *$ & $.28 * * *$ & .29 & .27 \\
\hline Lives in rural area & .11 & .10 & .17 & .15 \\
\hline Homeowner & $.64 * * *$ & $.78^{* * *}$ & $.81^{* * *}$ & $.87^{* * *}$ \\
\hline Good or very good health status & $.78 * * *$ & $.82 * * *$ & $.78 * * *$ & $.82 * * *$ \\
\hline Working & $.77 * * *$ & $.83 * * *$ & $.87 * * *$ & $.92 * * *$ \\
\hline \multicolumn{5}{|l|}{ Occupation } \\
\hline Professional & $.42 * * *$ & $.55^{* * *}$ & $.46 * * *$ & $.54 * * *$ \\
\hline Clerical & .09 & .08 & .09 & .08 \\
\hline Service & $.19 * * *$ & $.13 * * *$ & $.13^{* *}$ & $.10^{* *}$ \\
\hline Farm /fish & $.05^{* *}$ & $.04^{* *}$ & $.08^{* * *}$ & $.05^{* * *}$ \\
\hline Skilled trade & $.18^{* *}$ & $.14^{* *}$ & .17 & .17 \\
\hline Unskilled trade & $.08^{*}$ & $.07 *$ & .08 & .07 \\
\hline
\end{tabular}

Notes: P-values are from t-tests for differences in means between leavers and stayers. ${ }^{*} \mathrm{p}<.10 ;{ }^{*} \mathrm{p}<$ $.05 ; * * * p<.01$. The sample size used in the weighted sample is slightly smaller than the unweighted sample because of missing weights. Sample size varies for each characteristic because all available data were used. 
Appendix Table 2: Short- and Longer-Term Effects of Economic Crisis in Iceland on Hours of Work, Real Household Income, and Anxiety or Poor Mental Health-Fixed-Effects Models ( $N=6,711$ person years)

\begin{tabular}{|c|c|c|c|c|c|c|}
\hline & \multicolumn{2}{|c|}{ Hours of Work } & \multicolumn{2}{|c|}{$\begin{array}{l}\text { Real Household } \\
\text { Income }\end{array}$} & \multicolumn{2}{|c|}{$\begin{array}{c}\text { Anxiety or Poor Mental } \\
\text { Heath }\end{array}$} \\
\hline 2009 indicator & $-1.694 * * *$ & $-1.861 * * *$ & $-1.396 * * *$ & $-1.400 * * *$ & $0.029 * *$ & $0.030 * *$ \\
\hline 2012 indicator & -0.825 & $-1.078 *$ & $-1.132 * * *$ & $-1.163 * * *$ & 0.014 & 0.017 \\
\hline Time-varying covariates & No & Yes & No & Yes & No & Yes \\
\hline
\end{tabular}

Notes: Sample weights are applied. Figures are regression coefficients for effects of the crisis (2009 and 2012 indicator) relative to 2007. Time-varying covariates are married, cohabiting, lives with adult other than partner, and lives in rural area. All coefficients of 2009 crisis are statistically significant at $p<.01$.

Appendix Table 3: Estimated Effects of Mediators on Health-Compromising Behaviors-Fixed-Effects Models

\begin{tabular}{|l|c|c|c|c|c|c|}
\hline & Smoking & $\begin{array}{c}\text { Heavy } \\
\text { Drinking }\end{array}$ & $\begin{array}{c}\text { Daily } \\
\text { Sugared } \\
\text { Soft Drink }\end{array}$ & $\begin{array}{c}\text { Daily } \\
\text { Sweets }\end{array}$ & $\begin{array}{c}\text { Weekly } \\
\text { Fast Food }\end{array}$ & $\begin{array}{c}\text { Indoor } \\
\text { Tanning }\end{array}$ \\
\hline Hours of work & 0.000 & 0.001 & -0.000 & -0.000 & $0.001^{*}$ & 0.000 \\
\hline $\begin{array}{l}\text { Real household income } \\
\text { (millions of 2007 } \\
\text { krona/year) }\end{array}$ & $0.008^{* * *}$ & -0.001 & 0.002 & -0.002 & $0.007^{*}$ & -0.000 \\
\hline $\begin{array}{l}\text { Anxiety or poor mental } \\
\text { health }\end{array}$ & -0.003 & -0.005 & -0.001 & 0.003 & -0.026 & $0.030^{*}$ \\
\hline $\mathbf{N}$ (person years) & $\mathbf{6 , 4 3 8}$ & $\mathbf{6 , 4 9 5}$ & $\mathbf{6 , 4 9 8}$ & $\mathbf{6 , 4 8 6}$ & $\mathbf{6 , 5 5 5}$ & $\mathbf{6 , 1 1 1}$ \\
\hline
\end{tabular}

Appendix Table 4: Estimated Effects of Mediators on Health-Promoting Behaviors-Fixed-Effects Models

\begin{tabular}{|l|c|c|c|c|}
\hline & Daily Fruit & Daily Fish Oil & $\begin{array}{c}\text { Daily Vitamins/ } \\
\text { Supplements }\end{array}$ & $\begin{array}{c}\text { Recommended } \\
\text { Sleep }\end{array}$ \\
\hline Hours of work & 0.001 & -0.001 & -0.000 & $0.001^{* * *}$ \\
\hline $\begin{array}{l}\text { Real household income } \\
\text { (millions of 2007 } \\
\text { krona/year) }\end{array}$ & $-0.008^{* *}$ & -0.003 & 0.001 & -0.000 \\
\hline $\begin{array}{l}\text { Anxiety or poor mental } \\
\text { health }\end{array}$ & -0.013 & 0.009 & -0.020 & $-0.046^{* * *}$ \\
\hline $\mathbf{N}$ (person years) & $\mathbf{6 , 5 2 2}$ & $\mathbf{6 , 4 6 2}$ & $\mathbf{6 , 3 3 3}$ & $\mathbf{6 , 5 0 7}$ \\
\hline
\end{tabular}

Notes to Appendix Tables 3 and 4: Sample weights are applied. Figures presented are regression coefficients of the mediators from the models in the last rows of Tables $2 \& 3$. That is, for each behavior, all mediators are included in the same model that also controls for time-varying covariates (married, cohabiting, lives with adult other than partner, homeowner and lives in rural area). ${ }^{*} p<.10 ;{ }^{*} p<.05 ;{ }^{* *} p<.01$. 
Appendix Table 5: Short- and Longer-Term Effects of Economic Crisis in Iceland on HealthCompromising Behaviors-Fixed-Effects Models for Subsample Aged 25-61 Years

\begin{tabular}{|l|c|c|c|c|c|c|}
\hline & Smoking & $\begin{array}{c}\text { Heavy } \\
\text { Drinking }\end{array}$ & $\begin{array}{c}\text { Daily } \\
\text { Sugared } \\
\text { Soft Drink }\end{array}$ & $\begin{array}{c}\text { Daily } \\
\text { Sweets }\end{array}$ & $\begin{array}{c}\text { Weekly } \\
\text { Fast Food }\end{array}$ & $\begin{array}{c}\text { Indoor } \\
\text { Tanning }\end{array}$ \\
\hline Analysis sample, with: & & & & & & \\
\hline No covariates & & & & & & \\
\hline Effect of 2009 indicator & $-0.040^{* * *}$ & $-0.026^{* *}$ & $-0.017^{* *}$ & $-0.026^{* * *}$ & $-0.069^{* * *}$ & $-0.037^{* * *}$ \\
\hline Effect of 2012 indicator & $-0.054^{* * *}$ & $-0.028^{* *}$ & $-0.022^{* * *}$ & -0.012 & $-0.094^{* * *}$ & $-0.094^{* * *}$ \\
\hline $\begin{array}{l}\text { p-value for difference } \\
\text { between 2009 and 2012 }\end{array}$ & 0.109 & 0.865 & 0.509 & 0.145 & 0.050 & 0.000 \\
\hline Time-varying covariates & & & & & & \\
\hline Effect of 2009 indicator & $-0.041^{* * *}$ & $-0.027^{* * *}$ & $-0.016^{*}$ & $-0.026^{* * *}$ & $-0.069^{* * *}$ & $-0.040^{* * *}$ \\
\hline Effect of 2012 indicator & $-0.055^{* * *}$ & $-0.029^{* * *}$ & $-0.021^{* *}$ & -0.013 & $-0.094^{* * *}$ & $-0.100^{* * *}$ \\
\hline $\begin{array}{l}\text { p-value for difference } \\
\text { between 2009 and 2012 }\end{array}$ & 0.111 & 0.799 & 0.534 & 0.159 & 0.047 & 0.000 \\
\hline $\begin{array}{l}\text { Time-varying covariates } \\
\text { plus mediators }\end{array}$ & & & & & & \\
\hline Effect of 2009 indicator & $-0.029^{* * *}$ & $-0.020^{*}$ & -0.013 & $-0.028^{* * *}$ & $-0.066^{* * *}$ & $-0.039^{* * *}$ \\
\hline Effect of 2012 indicator & $-0.045^{* * *}$ & $-0.023^{* *}$ & $-0.018^{* *}$ & $-0.014^{*}$ & $-0.092^{* * *}$ & $-0.099^{* * *}$ \\
\hline $\begin{array}{l}\text { p-value for difference } \\
\text { between 2009 and 2012 }\end{array}$ & 0.111 & 0.790 & 0.534 & 0.156 & 0.046 & 0.000 \\
\hline \multicolumn{1}{|c|}{$\mathbf{N}$ (person years) } & $\mathbf{4 , 5 0 3}$ & $\mathbf{4 , 5 3 9}$ & $\mathbf{4 , 5 1 2}$ & $\mathbf{4 , 4 9 1}$ & $\mathbf{4 , 5 3 6}$ & $\mathbf{4 , 2 5 7}$ \\
\hline
\end{tabular}

Analysis sample consists of respondents completing all 3 interviews who had non-missing data on the outcome and all of the time-varying covariates and potential mediators. Time-varying covariates are married, cohabiting, lives with adult other than partner, lives in rural area, and homeowner. Mediators are hours of work, real income, and anxiety or poor mental health. ${ }^{* *} \mathrm{p}<.10 ;{ }^{* *} \mathrm{p}<.05 ;{ }^{*} \mathrm{p}<.01$. 
Appendix Table 6: Short- and Longer-Term Effects of Economic Crisis in Iceland on Health-Promoting Behaviors-Fixed-Effects Models for Subsample Aged 25-61 Years

\begin{tabular}{|l|c|c|c|c|}
\hline & $\begin{array}{c}\text { Daily } \\
\text { Fruit }\end{array}$ & $\begin{array}{c}\text { Daily } \\
\text { Fish Oil }\end{array}$ & $\begin{array}{c}\text { Daily } \\
\text { Vitamins }\end{array}$ & $\begin{array}{c}\text { Recommended } \\
\text { Sleep }\end{array}$ \\
\hline Analysis sample, with: & & & & \\
\hline No covariates & & & & \\
\hline Effect of 2009 indicator & -0.024 & $0.046^{* * *}$ & -0.004 & $0.034^{* *}$ \\
\hline Effect of 2012 indicator & $0.059^{* * *}$ & $0.113^{* * *}$ & $0.048^{* * *}$ & 0.006 \\
\hline $\begin{array}{l}\text { p-value for difference between } \\
\text { 2009 and 2012 }\end{array}$ & 0.000 & 0.000 & 0.001 & 0.049 \\
\hline Time-varying covariates & & & & -0.005 \\
\hline Effect of 2009 indicator & $-0.025^{*}$ & $0.048^{* * *}$ & $0.029^{* *}$ \\
\hline Effect of 2012 indicator & $0.056^{* * *}$ & $0.115^{* * *}$ & $0.045^{* * *}$ & -0.003 \\
\hline $\begin{array}{l}\text { p-value for difference between } \\
\text { 2009 and 2012 }\end{array}$ & 0.000 & 0.000 & 0.002 & 0.031 \\
\hline $\begin{array}{l}\text { Time-varying covariates plus } \\
\text { mediators }\end{array}$ & & & & \\
\hline Effect of 2009 indicator & $-0.032^{* *}$ & $0.037^{* *}$ & -0.017 & $0.034^{* *}$ \\
\hline Effect of 2012 indicator & $0.050^{* * *}$ & $0.106^{* * *}$ & $0.035^{* *}$ & 0.002 \\
\hline $\begin{array}{l}\text { p-value for difference between } \\
\text { 2009 and 2012 }\end{array}$ & 0.000 & 0.000 & 0.002 & 0.030 \\
\hline \multicolumn{1}{|c|}{$\mathbf{N}$ (person years) } & $\mathbf{4 , 5 1 2}$ & $\mathbf{4 , 4 6 7}$ & $\mathbf{4 , 4 2 8}$ & $\mathbf{4 , 5 0 3}$ \\
\hline
\end{tabular}

Notes: Sample weights are applied. Figures for effects of 2009 and 2012 indicators are regression coefficients. Analysis sample consists of respondents completing all 3 interviews who had non-missing data on the outcome and all of the time-varying covariates and potential mediators. Time-varying covariates are married, cohabiting, lives with adult other than partner, lives in rural area, and homeowner. Mediators are hours of work, real income, and anxiety or poor mental health $* * * p<.10 ; * *<.05 ; *^{*}<.01$. 
Appendix Table 7: Pooled Probit Results-Effects of Economic Crisis in Iceland on Health-

Compromising Behaviors

\begin{tabular}{|l|c|c|c|c|c|c|}
\hline & Smoking & $\begin{array}{c}\text { Heavy } \\
\text { Drinking }\end{array}$ & $\begin{array}{c}\text { Daily } \\
\text { Sugared } \\
\text { Soft Drink }\end{array}$ & $\begin{array}{c}\text { Daily } \\
\text { Sweets }\end{array}$ & $\begin{array}{c}\text { Weekly } \\
\text { Fast Food }\end{array}$ & $\begin{array}{c}\text { Indoor } \\
\text { Tanning }\end{array}$ \\
\hline & $\mathrm{ME}$ & $\mathrm{ME}$ & $\mathrm{ME}$ & $\mathrm{ME}$ & $\mathrm{ME}$ & $\mathrm{ME}$ \\
\hline $\mathbf{2 0 0 9}$ indicator & $-0.026^{* * *}$ & -0.012 & -0.003 & $-0.019^{* * *}$ & $-0.027^{* *}$ & -0.013 \\
\hline $\mathbf{2 0 1 2}$ indicator & $-0.044^{* * *}$ & -0.016 & -0.004 & -0.001 & -0.004 & $-0.058^{* * *}$ \\
\hline Age & $0.013^{* * *}$ & $-0.009^{* * *}$ & $-0.006^{* * *}$ & -0.001 & $-0.022^{* * *}$ & $-0.010^{* * *}$ \\
\hline Age squared & $-0.000^{* * *}$ & $0.000^{*}$ & 0.000 & 0.000 & $0.000^{* *}$ & 0.000 \\
\hline Male & -0.019 & $0.191^{* * *}$ & $0.040^{* * *}$ & -0.012 & $0.161^{* * *}$ & $-0.082^{* * *}$ \\
\hline $\begin{array}{l}\text { High school or } \\
\text { less }\end{array}$ & $0.176^{* * *}$ & 0.027 & $0.085^{* * *}$ & -0.022 & -0.030 & $0.128^{* * *}$ \\
\hline Some college & $0.099^{* * *}$ & -0.011 & $0.044^{* *}$ & -0.008 & 0.049 & $0.110^{* * *}$ \\
\hline $\begin{array}{l}\text { Undergraduate } \\
\text { degree }\end{array}$ & 0.037 & -0.014 & 0.002 & 0.010 & 0.046 & 0.035 \\
\hline $\mathbf{N}$ & $\mathbf{6 , 4 3 2}$ & $\mathbf{6 , 4 8 6}$ & $\mathbf{6 , 6 2 9}$ & $\mathbf{6 , 4 8 0}$ & $\mathbf{6 , 5 4 9}$ & $\mathbf{6 , 1 0 8}$ \\
\hline
\end{tabular}

Appendix Table 8: Pooled Probit Results-Effects of Economic Crisis in Iceland on Health-Promoting Behaviors

\begin{tabular}{|l|c|c|c|c|}
\hline & $\begin{array}{c}\text { Daily } \\
\text { Fruit }\end{array}$ & $\begin{array}{c}\text { Daily } \\
\text { Fish Oil }\end{array}$ & $\begin{array}{c}\text { Daily } \\
\text { Vitamins }\end{array}$ & $\begin{array}{c}\text { Recommended } \\
\text { Sleep }\end{array}$ \\
\hline & $\mathrm{ME}$ & $\mathrm{ME}$ & $\mathrm{ME}$ & $\mathrm{ME}$ \\
\hline $\mathbf{2 0 0 9}$ indicator & $-0.039^{* * *}$ & $0.027^{*}$ & -0.009 & $0.026^{* *}$ \\
\hline $\mathbf{2 0 1 2}$ indicator & $0.029^{* *}$ & $0.077^{* * *}$ & $0.041^{* * *}$ & -0.002 \\
\hline Age & $0.007^{*}$ & -0.002 & -0.001 & 0.001 \\
\hline Age squared & -0.000 & $0.000^{* * *}$ & $0.000^{* *}$ & -0.000 \\
\hline Male & $-0.206^{* * *}$ & $-0.060^{* * *}$ & $-0.219^{* * *}$ & -0.020 \\
\hline High school or less & $-0.111^{* * *}$ & $-0.088^{* * *}$ & -0.048 & $-0.111^{* * *}$ \\
\hline Some college & $-0.069^{* *}$ & -0.047 & -0.017 & $-0.063^{* *}$ \\
\hline Undergraduate degree & -0.018 & -0.025 & -0.045 & -0.043 \\
\hline $\mathbf{N}$ & $\mathbf{6 , 5 1 6}$ & $\mathbf{6 , 4 5 6}$ & $\mathbf{6 , 3 2 7}$ & $\mathbf{6 , 4 9 8}$ \\
\hline
\end{tabular}

Notes to Appendix Tables 7 and 8: Sample weights are applied. "2009 indicator" captures the effect of the crisis (that is, it is relative to 2007). ME = marginal effect. ${ }^{*} p<.10 ; * *<.05 ;{ }^{* * *} p<.01$. 